\title{
Source Identification and Human Health Risk of Heavy Metals in Soil: a Case Study of Industrial Areas of Northeast China
}

\author{
Jiaxi Tang ${ }^{1,2}$, Yongle Zhu ${ }^{1}$, Zhongping Wei ${ }^{3}$, Liangshan Feng ${ }^{2}$, Ning Yang ${ }^{2}$, \\ Qing Luo ${ }^{4 *}$, Tao Kong ${ }^{1}$ \\ ${ }^{1}$ College of Environmental Science and Engineering, Liaoning Technical University, Fuxin 123000, China \\ ${ }^{2}$ Liaoning Academy of Agricultural Sciences, Shenyang 110161, China \\ ${ }^{3}$ Liaoning Academy of Forestry Science, Shenyang 110032, China \\ ${ }^{4}$ Key Laboratory of Regional Environment and Eco-Remediation of Ministry of Education, \\ College of Environment, Shenyang University, Shenyang 110044, China
}

Received: 21 December 2020

Accepted: 11 February 2021

\begin{abstract}
The objectives of this study were to identify the sources and concentrations of heavy metals in soils from typical industrial areas in Fuxin, China and assess potential ecological and health risks. A total of 52 surface soil samples from sites A and B were collected and analyzed for $\mathrm{Cd}, \mathrm{Pb}, \mathrm{Cr}, \mathrm{Cu}, \mathrm{Ni}, \mathrm{Zn}, \mathrm{As}$, and $\mathrm{Hg}$. Results showed that all concentrations of heavy metals exceeded background values to varying degrees, especially for $\mathrm{Cd}$. The mean concentrations for $\mathrm{Cd}, \mathrm{Pb}, \mathrm{Cr}, \mathrm{Cu}, \mathrm{Ni}, \mathrm{Zn}$, As, and $\mathrm{Hg}$ in sites $\mathrm{A}$ and site $\mathrm{B}$ were $1.31 \pm 0.97$ and $1.23 \pm 0.65 \mathrm{mg} \cdot \mathrm{kg}^{-1}, 12.54 \pm 12.45$ and $8.51 \pm 8.85 \mathrm{mg} \cdot \mathrm{kg}^{-1}, 48.26 \pm 26.62$ and $33.20 \pm 31.67 \mathrm{mg} \cdot \mathrm{kg}^{-1}, 23.29 \pm 27.40$ and $23.98 \pm 28.71 \mathrm{mg} \cdot \mathrm{kg}^{-1}, 63.01 \pm 34.44$ and $50.21 \pm 10.99 \mathrm{mg} \cdot \mathrm{kg}^{-1}$, $114.07 \pm 52.26$ and $108.60 \pm 41.75 \mathrm{mg} \cdot \mathrm{kg}^{-1}, 10.45 \pm 0.80$ and $9.80 \pm 1.17 \mathrm{mg} \cdot \mathrm{kg}^{-1}$, and $0.045 \pm 0.072$ and $0.06 \pm 0.05 \mathrm{mg} \cdot \mathrm{kg}^{-1}$, respectively, indicating that these metals were enriched in the surface soil of the study areas. Site A only reaches a low risk degree, and site B is of medium risk degree. This difference is due to the diverse industry distributions and pollution emissions. Related control and measure should be drawn up from noncancer and cancer risks for children and adults.
\end{abstract}

Keywords: heavy metal, industrial soil, risk assessment, sources

\section{Introduction}

Rapid urbanization and industrialization provide benefits to the economy and society but also cause pollution of soil, water, and air and even pose risks

*e-mail: luoqingyt@126.com to ecosystems [1-4]. Heavy metals refer to metals and metalloids, such as $\mathrm{Cr}, \mathrm{Cu}, \mathrm{Zn}, \mathrm{As}, \mathrm{Cd}, \mathrm{Ni}, \mathrm{Pb}$, and $\mathrm{Hg}$, whose densities are $>5 \mathrm{~g} \cdot \mathrm{cm}^{-3}$ [5-6]. Heavy metals in soil are difficult to degrade and enter the food chain. Consequently, heavy metal pollution will not only reduce the quality of the soil environment but also pose a threat to human health [7-12]. For instance, exposure to As can lead to dermal lesions, skin cancer, peripheral neuropathy, and peripheral vascular disease 
[13]. Sources of heavy metals due to human activities include mineral resource extraction, metal processing and smelting, chemical production, fertilization, and transportation [14-17].

In the past 50 years, a large amount of $\mathrm{Pb}$ and $\mathrm{Cr}$ have been released into the environment worldwide, most of which have been enriched in soil [18-20]. Heavy metal-contaminated soil has become a serious problem in many parts of the world, including China [20-24]. In particular, evident heavy metal pollution is observed in soil surrounding industrial activities [19], and the most common heavy metals are $\mathrm{Cd}, \mathrm{Pb}, \mathrm{Cr}, \mathrm{Cu}, \mathrm{As}, \mathrm{Ni}$, and $\mathrm{Hg}$. Industrial activities are the main cause of heavy metal pollution in soil [25-26].

Most previous studies focused on a typical industrial area when measuring the concentration of heavy metals at sampling points and then assessing the level of pollution and associated risks [27]. For instance, $\mathrm{Li}$ et al. measured and assessed $\mathrm{Cd}, \mathrm{Pb}, \mathrm{Cu}, \mathrm{Zn}$, and $\mathrm{Cr}$ heavy metals in the soil around a mining area in Henan Province, China. They concluded that these heavy metals contaminated the soil of sampling sites to varying degrees, with obvious potential ecological risks. In particular, the risk index of Cd was the highest, contributing the most to the risk [28]. Wu found that the urban soils around electronic manufacturing facilities were evidently polluted by heavy metals [29]. The total contents of $\mathrm{Cr}, \mathrm{Cu}, \mathrm{Zn}, \mathrm{As}, \mathrm{Cd}, \mathrm{Ni}$, and $\mathrm{Pb}$ were the highest in commercial area soils. The order of human health risk index was $\mathrm{Cr}>\mathrm{As}>\mathrm{Pb}>\mathrm{Cd}>\mathrm{Cu}>\mathrm{Ni}>\mathrm{Zn}$. The carcinogenic risk of $\mathrm{Cr}$ and $\mathrm{As}$ was more than $10^{-4}$, and that in children was higher than that in adults. The distribution of a number of heavy metals in soil from an informal recycling site in the largest market for used and new electronics and electrical equipment in West
Africa was investigated by Isimekhai et al. [30], and the potential risk due to the recycling activities was also assessed. They found that the concentration of the total heavy metals decreased as follows: $\mathrm{Cu}>\mathrm{Pb}>\mathrm{Zn}$ $>\mathrm{Mn}>\mathrm{Ni}>\mathrm{Sb}>\mathrm{Cr}>\mathrm{Cd}$. The highest concentration was found in the area where the burning of the waste occurs, but $\mathrm{Cd}$ showed the highest potential environmental risk in the study site. Similarly, Singh et al. researched the effects of heavy metals on the adults and children working in informal e-waste recycling sectors of Chandigarh and Ludhiana, Punjab, India. E-waste recycling activities release heavy metals into the atmosphere, including air, soil, and dust, which causes adverse health effects on the workers [31]. However, reviews on soil heavy metal pollution in different types of industrial areas are limited. Therefore, studying the concentrations and levels of heavy metal pollution in different types of industrial land and comparing and analyzing its potential ecological and health risks are necessary, which would provide a basis for targeted control to improve soil quality.

\section{Materials and Methods}

\section{Study and Sample Areas}

Fuxin city is a rectangle with its central axis intersecting the intersection of $42^{\circ} 10 \mathrm{~N}$ and $122^{\circ} 00 \mathrm{E}$ with a total area of $10326.9853 \mathrm{~km}^{2}$. Fuxin City has abundant mineral resources, coal, silica sand, gold and other reserves. Because of the good resource conditions, the industrial system is more developed, mainly concentrating on chemical industry, agate industry, gold mining and so on. Fuxin city is known as the fluorine

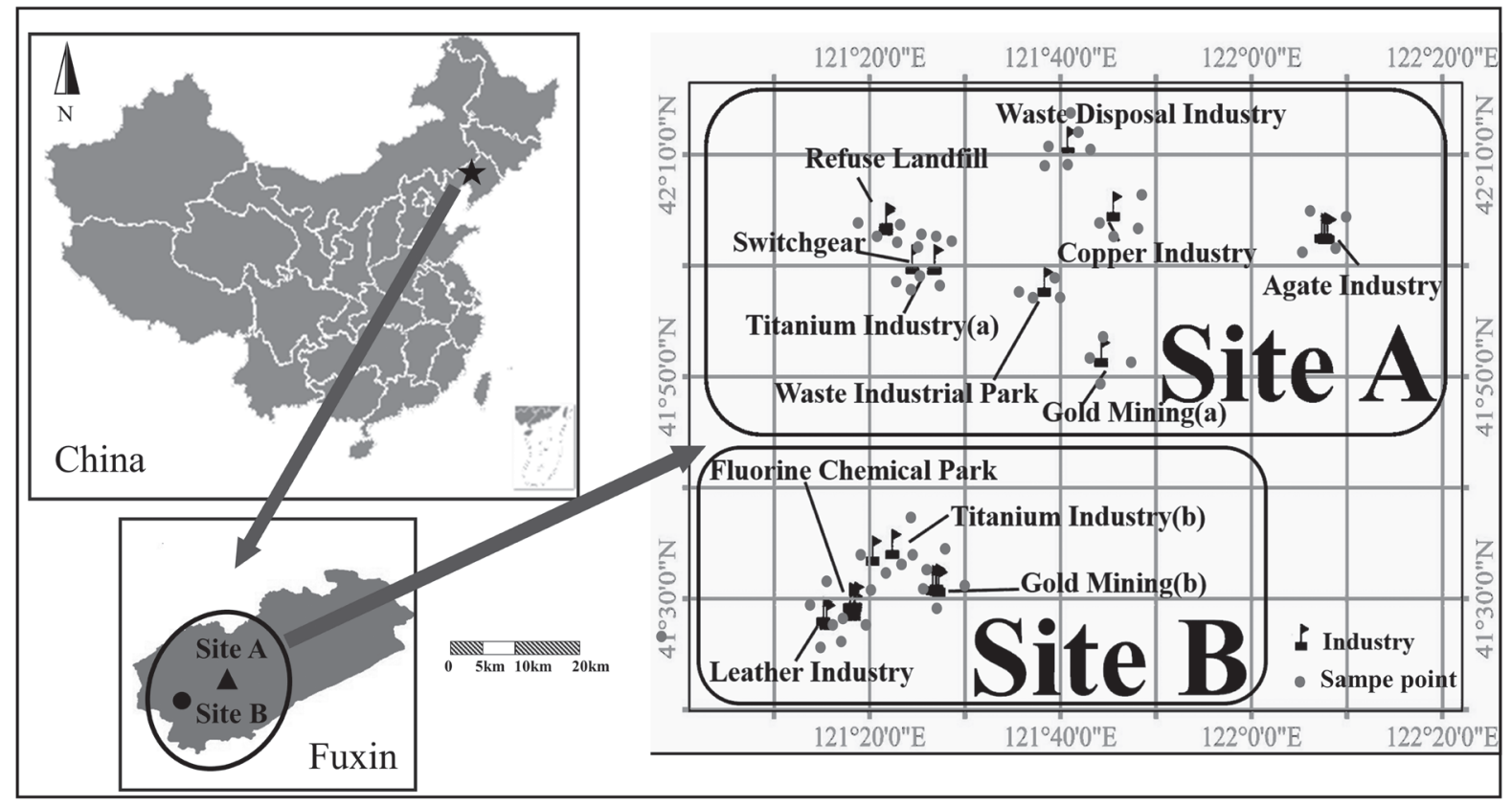

Fig. 1. Geographical location of certain key monitoring industries and division for site A and site B in Fuxin, Liaoning, China. 
capital of China because of two famous fluorine industrial parks. It is noticed that this study is mainly aimed at the key monitoring industries in Fuxin city, monitoring the content of heavy metals in industries and its surrounding surface soils. Agricultural land is distributed around the industries, and agricultural activities also have certain impact on heavy metals. The pollutant emission components of these key monitoring industries are diverse. Therefore, according to the location of the industries, the characteristics of the industries, these key monitoring industries are divided into two areas (site A and site B), listed in Fig. 1 The abbreviation for different industry is listed in Table S1. Sampling points are distributed around the industries. Through the division of the whole industrial areas, a more reasonable regional study is carried out.

\section{Soil Sampling and Analysis}

In this study, a total of 52 surface soil samples were collected. The tool of sample collecting is wooden shovel, sampling depth is $0-20 \mathrm{~cm}$. Mixed samples were collected and the soil samples were stored mainly in plastic self-sealing bags. Each soil sample is about $2 \mathrm{~kg}$, which are collected kept away from light. All soil samples shall be air dried, ground and sieved 100 mesh sieve before treated with chemical reagent. The above chemical treatment methods for heavy metals coming from [32], are listed in Supplementary Materials (SM). Sample points are surrounding with agriculture land, so the agriculture assessment of the background and risk screening value is used according to different $\mathrm{pH}$. Meanwhile, the background value and the risk screening value are listed in Table S2.

\section{Potential Ecological and Health Risk Assessment}

In this study, geological accumulation index (Igeo), potential ecological and health risk assessment are used for the main models. Igeo and potential ecological risk is assessed with the level of heavy metals contamination. Igeo not only takes into account the influence of background value caused by natural geological processes, but also pays full attention to the influence of human activities on heavy metal pollution. This is an important parameter to distinguish the impact of human activities [33-34]. Ecological risk is used to assess the effects of heavy metals on the process of pollution in the soil. Heavy metals in soil can cause pollution to the environment, so it is necessary to judge the pollution degree of different heavy metals in site A and site B by ecological risk. Health risk is assessed to describe the probability of non-carcinogenic and carcinogenic of heavy metals in human body. In this study, adults and children were selected as exposed populations, mainly through three ways for ingestion, dermal contact and inhalation. Details of concrete formulas and methods for the three models are shown in the SM.

\section{Statistical Analysis}

This study analyzed the concentration of eight heavy metals in the surface soil samples collected in the industrial areas. Position determination by using the Arcgis 10.7. The correlation analysis, hierarchical cluster analysis (HCA) and principal component analysis (PCA) of the data are used the IBM SPSS Statistics 22., and Excel 2013 for mapping.

\section{Results and Discussion}

\section{Pollution Concentration of Heavy Metals in Soil}

The concentrations of eight heavy metals in sites A and B and their local background [32] and risk screening values [35] are listed in Table 1. Heavy metals are still enriched in the surrounding soil of industrial areas by their unchanging nature and different migration [36-38]. Thus, high concentrations are detected. The mean concentrations of the heavy metals in site $\mathrm{A}$ are as follows: $\mathrm{Zn} \quad\left(114.07 \pm 52.26 \mathrm{mg} \cdot \mathrm{kg}^{-1}\right)>\mathrm{Ni}$ $\left(63.01 \pm 34.44 \mathrm{mg} \cdot \mathrm{kg}^{-1}\right)>\mathrm{Cr} \quad\left(48.26 \pm 26.62 \mathrm{mg} \cdot \mathrm{kg}^{-1}\right)>\mathrm{Cu}$ $\left(23.29 \pm 27.40 \mathrm{mg} \cdot \mathrm{kg}^{-1}\right)>\mathrm{Pb} \quad\left(12.54 \pm 12.45 \mathrm{mg} \cdot \mathrm{kg}^{-1}\right)>\mathrm{Cd}$ $\left(1.31 \pm 0.97 \mathrm{mg} \cdot \mathrm{kg}^{-1}\right)>\mathrm{Hg}\left(0.045 \pm 0.072 \mathrm{mg} \cdot \mathrm{kg}^{-1}\right)$. The mean concentrations of heavy metals in site $\mathrm{B}$ are as follows: $\mathrm{Zn} \quad\left(108.60 \pm 41.75 \mathrm{mg} \cdot \mathrm{kg}^{-1}\right)>\mathrm{Ni} \quad\left(50.21 \pm 10.99 \mathrm{mg} \cdot \mathrm{kg}^{-1}\right)$ $>\mathrm{Cr} \quad\left(33.20 \pm 31.67 \mathrm{mg} \cdot \mathrm{kg}^{-1}\right)>\mathrm{Cu} \quad\left(23.98 \pm 28.71 \mathrm{mg} \cdot \mathrm{kg}^{-1}\right)$ $>$ As $\quad\left(9.80 \pm 1.17 \mathrm{mg} \cdot \mathrm{kg}^{-1}\right)>\mathrm{Pb} \quad\left(8.51 \pm 8.58 \mathrm{mg} \cdot \mathrm{kg}^{-1}\right)>\mathrm{Cd}$ $\left(1.23 \pm 0.65 \mathrm{mg} \cdot \mathrm{kg}^{-1}\right)>\mathrm{Hg}\left(0.06 \pm 0.05 \mathrm{mg} \cdot \mathrm{kg}^{-1}\right)$. The order of the concentrations of heavy metals, except for $\mathrm{Pb}$ and $\mathrm{Cu}$, in the two regions is the same; the exception is related to the different industrial distributions. The total of mean concentration, except for that of $\mathrm{Hg}$, in site $\mathrm{A}$ is superior to that in site $\mathrm{B}$. Industry variety plays an important role in this result. The concentrations of $\mathrm{Cd}$ are $1.31 \pm 0.97$ and $1.23 \pm 0.65 \mathrm{mg} \cdot \mathrm{kg}^{-1}$, exceeding the background and risk screening values. The seven other heavy metal concentrations exceed the background value but not the risk screening value. This condition is ascribed to industrial processing and human interference. Concentrations of heavy metals below the corresponding background value are considered to represent the geochemical background of geological or natural origin. Values above the background value can be assumed to be outliers from anthropogenic origin [39]. Anthropogenic inputs of heavy metals are from industrialization, agricultural practices, urban impacts, traffic emissions, and other factors. Sites having mixed activities, such as metal manufacturing, include light industry areas. Car paint spraying and battery repair also contribute to the content of heavy metals [40].

A high concentration of heavy metals occurs in different industries, which is mainly related to human activities and industrial emissions. The agricultural lands around the industries contribute to the development 


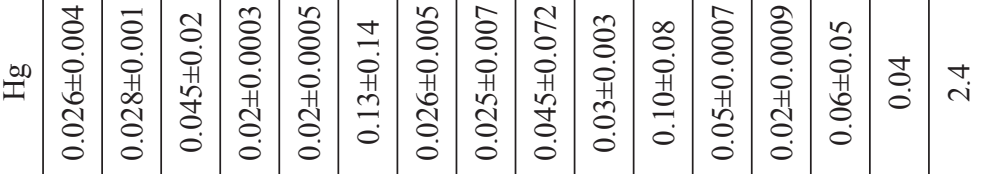

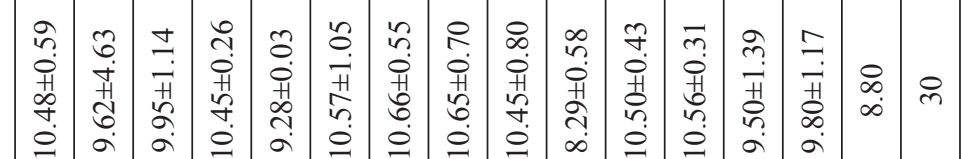

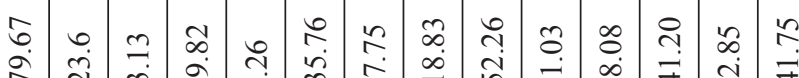

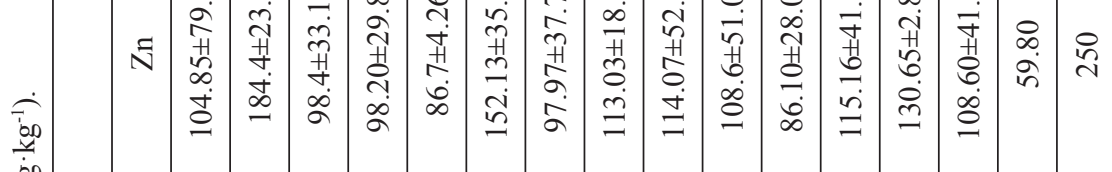

总

m.

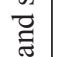

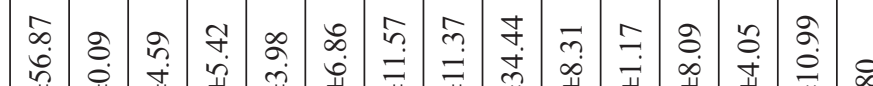

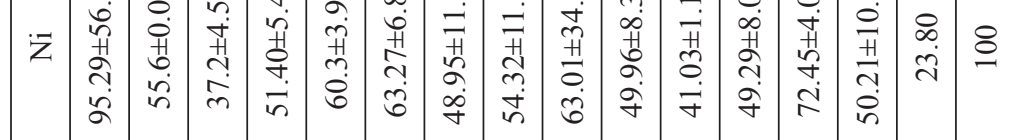

(1)

悹

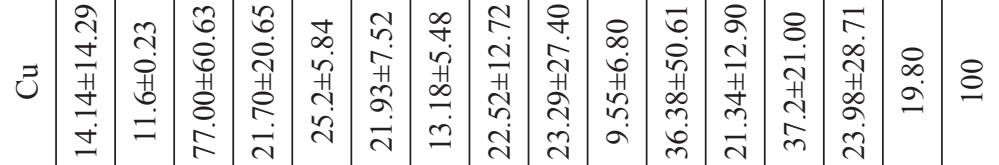

帝

글

奈

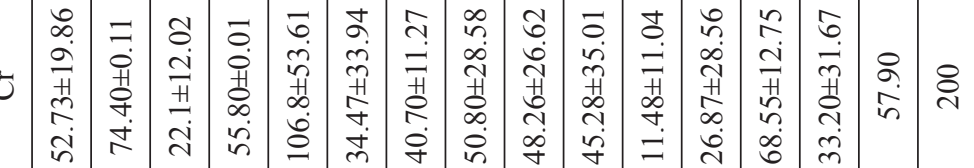

范

త్ర్ల

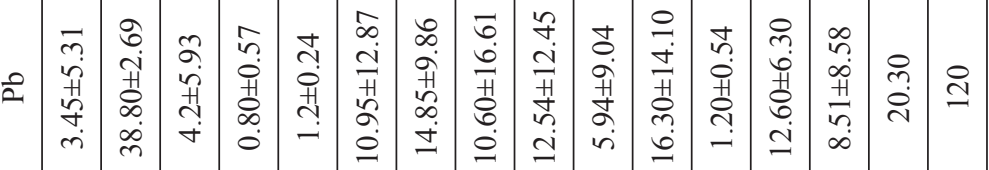

疍

茫

$\ddot{z}$

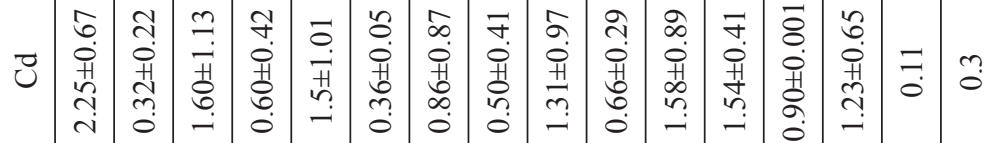

تే

Q

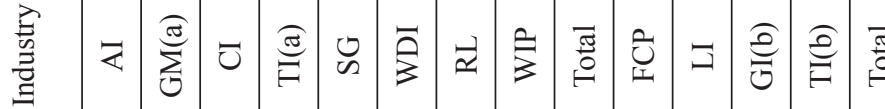

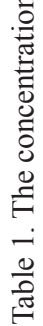


of human actions and lead to this phenomenon of heavy metal pollution. For sites $\mathrm{A}$ and $\mathrm{B}$, the regions have various industries with different heavy metal pollution. In site $\mathrm{A}$, the highest concentration of $\mathrm{Cd}$ or $\mathrm{Ni}$ comes from AI. The concentration of $\mathrm{Cd}$ is higher than the concentration in other industries and the mean concentration of site A $\left(1.31 \pm 0.97 \mathrm{mg} \cdot \mathrm{kg}^{-1}\right)$. Hence, AI emission in site $\mathrm{A}$ is the main source of $\mathrm{Cd}$ pollution. $\mathrm{Ni}$ mainly tends to exist in natural ores, which are often considered inexpensive materials in agate industries. This condition leads to the high concentration of $\mathrm{Ni}$ around $\mathrm{AI} . \mathrm{Pb}$ is a special metal and has some concentration in soils. The highest concentration of $\mathrm{Pb}$ is $38.80 \pm 2.69 \mathrm{mg} \cdot \mathrm{kg}^{-1}$ coming from GM (a). GM (a) is attributed to the substantial outputs of gold, but many emissions of $\mathrm{Pb}$ are released with the form of dust in the exploitation process. A high concentration of $\mathrm{Cr}$ is detected in SG. The concentration of $\mathrm{Cr}$ from $\mathrm{SG}$ is approximately twice the mean concentrations of site A. The process of switch production may release $\mathrm{Cr}$ to the environment. Meanwhile, the concentration of $\mathrm{Cr}$ in SG exerts a great effect on promoting the total concentration in site $\mathrm{A}$. For $\mathrm{Cu}$, industries around site A have a high concentration, especially for CI. Resource of $\mathrm{Cu}$ that will be released in different forms of dust or powder. On the basis of this situation, other industries may also produce related pollution of $\mathrm{Cu}$ from industrial production, but the main source may result from copper mine exploitation, in which dusts or powders are widespread. For $\mathrm{Zn}$ and $\mathrm{Hg}$, the highest concentrations are $152.13 \pm 35.76$ and $0.13 \pm 0.14 \mathrm{mg} \cdot \mathrm{kg}^{-1}$, respectively, all coming from WDI. Although WDI includes some heavy industries, it has stopped production for a long time because of the health problem it causes to local residents. However, this pollution effect from heavy metals is not eliminated in consideration of the concentration enrichment of $\mathrm{Zn}$ and $\mathrm{Hg}$. The important reason is that the pollution emission from previous industrial processes has not been controlled. $\mathrm{Zn}$ or $\mathrm{Hg}$ has stronger enrichment power than other metals. The metal concentration of As also has a great difference from that of other metals. The highest concentration of As is $10.66 \pm 0.55 \mathrm{mg} \cdot \mathrm{kg}^{-1}$ in $\mathrm{RL}$, but high concentrations also exist in other industrial areas. That is, many industries in site A produce As pollution to varying degrees, or the agricultural lands around the industries use seriously polluted water to irrigate crops massively. This phenomenon occurs only when a particular industrial system discharges wastes containing various heavy metals during manufacturing that accumulates in surface soil. Song indicated that solid waste is used to remove impurities. Precipitated and washing wastewater all contain heavy metals [41]. Etim analyzed heavy metal pollution from surface soil in southwest Nigeria. Improper disposal of industrial solid waste seems to be a possible source of metal pollution in industrial parks. Heavy metal pollution in industries can be greatly reduced by locating the generated solid waste and applying particulate scrubbers to the industries [42].

The number of industries for site B is less than that for site A. High metal concentrations exist in a certain part of industries, and this condition is related to production processing. LI presents the highest concentration of heavy metals, including $\mathrm{Cd}\left(1.58 \pm 0.89 \mathrm{mg} \cdot \mathrm{kg}^{-1}\right), \mathrm{Pb}$ $\left(16.30 \pm 14.10 \mathrm{mg} \cdot \mathrm{kg}^{-1}\right), \mathrm{Cu}\left(36.38 \pm 50.61 \mathrm{mg} \cdot \mathrm{kg}^{-1}\right)$, and $\mathrm{Hg}\left(0.10 \pm 0.08 \mathrm{mg} \cdot \mathrm{kg}^{-1}\right)$. The concentrations nearby LI

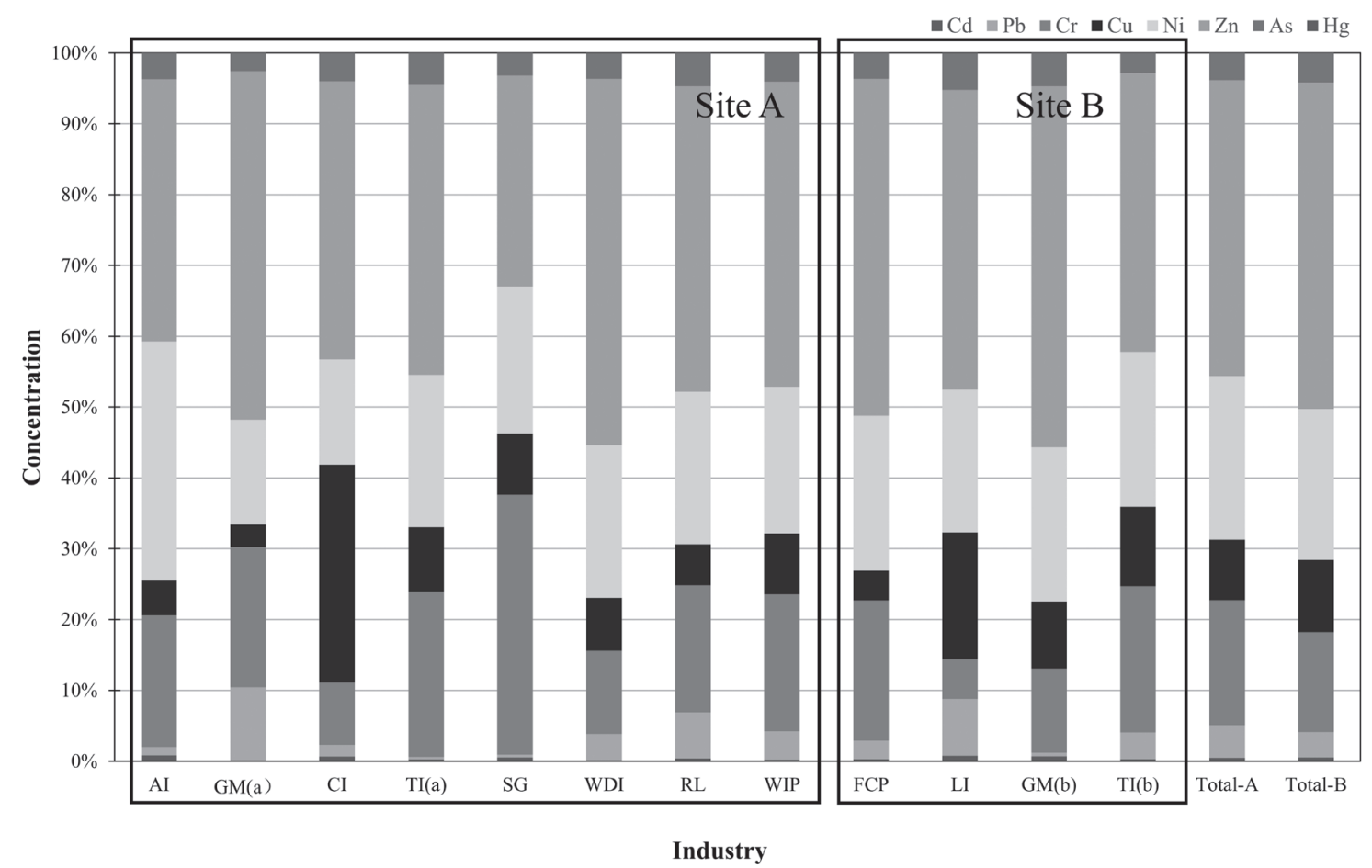

Fig. 2. The concentration of $\mathrm{Cd}, \mathrm{Pb}, \mathrm{Cr}, \mathrm{Cu}, \mathrm{Ni}, \mathrm{Zn}, \mathrm{As}$ and $\mathrm{Hg}$ from different industries in site $\mathrm{A}$ and site $\mathrm{B}$. 
exceed those in three other industries to a great extent. LI releases substantial wastewater from the processes of washing and dying into the local environment. The wastewater spreads across agricultural lands and drinking water and constantly harm the human body. The heavy concentrations around $\mathrm{TI}(\mathrm{b})$ are higher than those around $\mathrm{TI}(\mathrm{a})$, and the concentrations of $\mathrm{Cr}$ $\left(68.55 \pm 12.75 \mathrm{mg} \cdot \mathrm{kg}^{-1}\right), \quad \mathrm{Cu} \quad\left(37.2 \pm 21.00 \mathrm{mg} \cdot \mathrm{kg}^{-1}\right), \quad \mathrm{Ni}$ $\left(72.45 \pm 4.05 \mathrm{mg} \cdot \mathrm{kg}^{-1}\right)$, and $\mathrm{Zn}\left(130.65 \pm 2.85 \mathrm{mg} \cdot \mathrm{kg}^{-1}\right)$ indicate the highest values in site $\mathrm{B}$. Thus, TI(b) has a great contribution rate to total pollution level in site B. For As, a high concentration occurs in the two places of LI $\left(10.50 \pm 0.43 \mathrm{mg} \cdot \mathrm{kg}^{-1}\right)$ and $\mathrm{GI}(\mathrm{b})\left(10.56 \pm 0.31 \mathrm{mg} \cdot \mathrm{kg}^{-1}\right)$. Nevertheless, the heavy concentrations around FCP do not highly exceed the background and risk screening values, probably because this industrial region may have mature technology and equipment used to solve the pollution issue.

The distribution of the concentrations of the eight heavy metals in different industries in sites A and B is shown in Fig. 2. The distribution of heavy metals is basically similar, but the concentration has a great difference. In site $\mathrm{A}$, the contents of $\mathrm{Zn}$ in $\mathrm{GM}(\mathrm{a})$, $\mathrm{Cu}$ in $\mathrm{CI}$, and $\mathrm{Cr}$ in $\mathrm{SG}$ present a relatively high trend. In site $\mathrm{B}$, the concentrations of $\mathrm{Cr}, \mathrm{Cd}$, and $\mathrm{Cu}$ are all higher in $\mathrm{TI}(\mathrm{b})$ than in other industries. The two regions have parts with similar production in industries, such as GM(a) \& GM(b) and TI (a) \& TI(b). However, the contents of the eight heavy metals from gold and titanium industries are different and relate to geographic position. Although the industrialization processing has an indispensable effect on heavy metal contents, the geographic distribution may influence direct surface runoff, which can change the contents around industries directly. Meanwhile, the study regions have abundant mine resources, which are also a reason for the difference in concentration distribution of similar industries. Cheng et al. indicated that the risk caused by $\mathrm{Hg}$ is high in alum mine soil, whereas the risk caused by $\mathrm{Cd}$ is relatively high in coal mine soil [43]. This finding shows that heavy metal pollution will occur in the mining process of coal and metal mines, and it is closely related to ore composition. Persistent impact from human activities is always ignored in the pollution of heavy metals. Liu et al. demonstrated that all samples for pollution levels in industrial areas are seriously polluted by human sources [44].

The concentrations of different heavy metals in sites $\mathrm{A}$ and $\mathrm{B}$ and their comparison with background and risk screening values are shown in Fig. 3. More concentrations of heavy metals, except for $\mathrm{Cd}$, in site A exceed the background and risk screening values than in site B. Cd is approximately $82.35 \%$ above the background value $\left(0.11 \mathrm{mg} \cdot \mathrm{kg}^{-1}\right)$ and $79.41 \%$ above the risk screening value $\left(0.3 \mathrm{mg} \cdot \mathrm{kg}^{-1}\right)$ in site A. All concentrations are above the background value and $94.44 \%$ above the risk screening value in site B. As a result, the concentration of $\mathrm{Cd}$ has exceeded the standard. $\mathrm{Cd}$ in a local environment mainly comes from nonferrous metal smelting, ore sintering, and disposal of Cd-containing waste. The concentration of $\mathrm{Cd}$ in the soil near the metal smelter and downwind zone is excessively high, resulting in polluted lands. Although the concentration of $\mathrm{Cd}$ has exceeded the risk screening value of agricultural land, it does not exceed the risk screening value of industry land (20 $\left.\mathrm{mg} \cdot \mathrm{kg}^{-1}\right)$ [45]. The accumulation of Cd-containing waste residue introduces $\mathrm{Cd}$ compounds into soil and water [46-47]. For example, Gao et al. found that high $\mathrm{Cd}$ concentrations are distributed in the southern part of
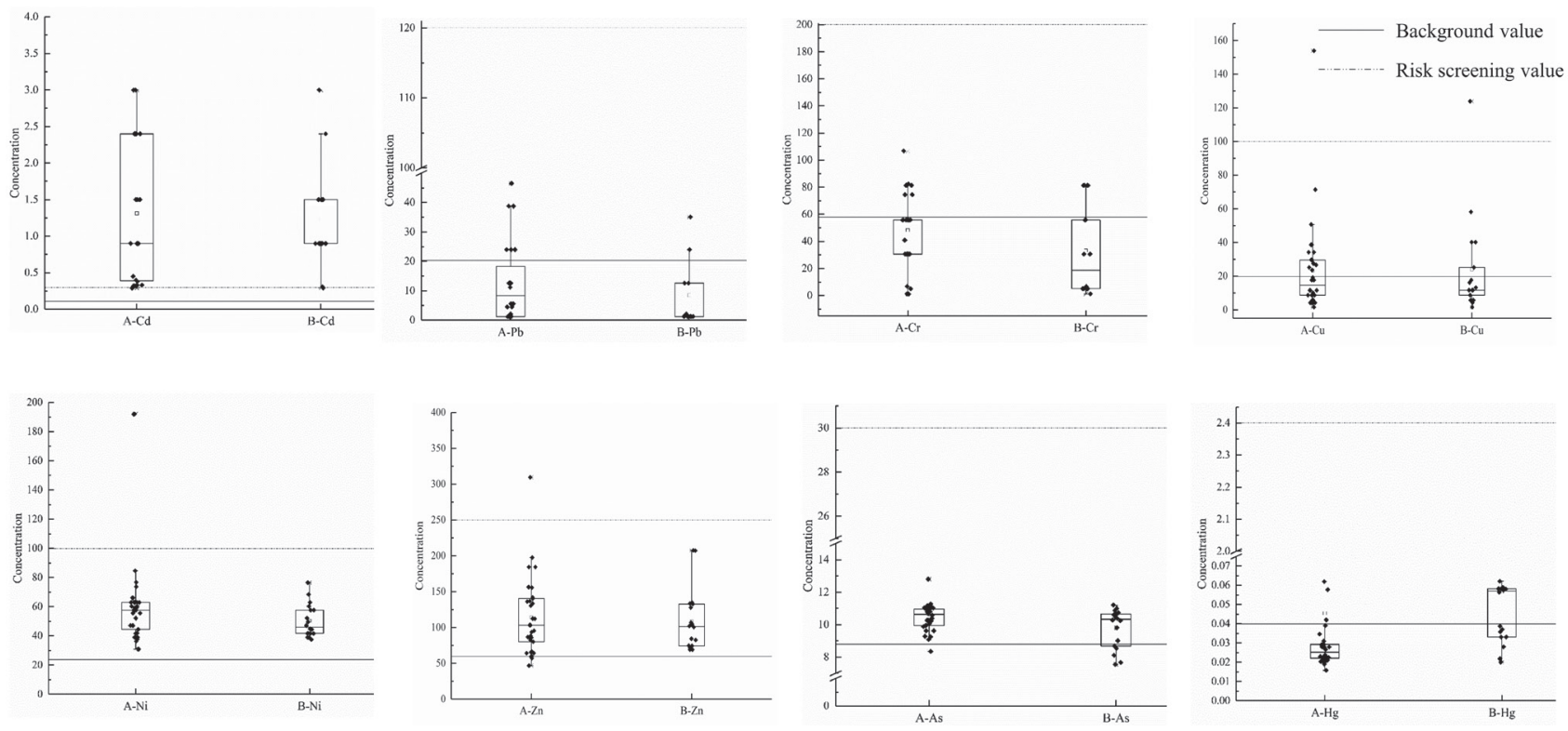

Fig. 3. Distribution of concentrations of $\mathrm{Cd}, \mathrm{Pb}, \mathrm{Cr}, \mathrm{Cu}, \mathrm{Ni}, \mathrm{Zn}, \mathrm{As}, \mathrm{Hg}$ in site $\mathrm{A}$, site $\mathrm{B}$ and comparison with local background value and risk screening value. 
Baosteel industry. Their main sources are production and processing, which may be due to the discharge of wastewater or sludge affected by production activities [48]. The study results of Gao et al. are similar to the results of the current study, in which the maximum concentration of $\mathrm{Cd}$ is distributed near a gold deposit. The concentrations of $\mathrm{Cd}$ in site $\mathrm{B}$ exceed the background and risk screening values to a great extent, but high concentrations of $\mathrm{Cd}$ appear in site A. This phenomenon is mainly because the concentration of $\mathrm{Cd}$ for some places in site $\mathrm{A}$ is lower than the detection limit, whereas the $\mathrm{Cd}$ concentration in site $\mathrm{B}$ tends to be stably higher than the background value.

$\mathrm{Pb}$ and $\mathrm{Cr}$ only partially exceed the local background values. In site $\mathrm{A}, 17.65 \%$ of $\mathrm{Pb}$ concentrations and $23.53 \%$ of $\mathrm{Cr}$ concentrations exceed the background values (20.3 and $57.9 \mathrm{mg} \cdot \mathrm{kg}^{-1}$, respectively). Approximately $11.11 \%$ of $\mathrm{Pb}$ concentrations and $22.22 \%$ of $\mathrm{Cr}$ concentrations exceed the background value in site $\mathrm{B} . \mathrm{Pb}$ is released into the environment from the main source of vehicle or equipment emissions. Roughly 200 vehicles worldwide emit approximately 400,000 exhaust each year, which has become the main source of this $\mathrm{Pb}$ pollution. Factories are also located on the roadside, even the edge of cities, to reduce transportation cost, which also causes $\mathrm{Pb}$ pollution [49-51]. Thus, $\mathrm{Pb}$ mainly comes from anthropogenic sources [52]. For Cr, previous studies have shown that its concentration fluctuations are strongly correlated with the total concentrations of all heavy metals, and $\mathrm{Cr}$ can be an important indicator of the degree of metal contamination [53].

$\mathrm{Ni}$ is one of the constituent elements in the crust. $\mathrm{Ni}$ in soil usually exists in the form of organic binding, and neutral conditions increase fluidity and bioavailability under acidic conditions. $\mathrm{Zn}$ has a high content in ore, mainly from zinc and gold ores. It exists in natural conditions, but industrial production and activities increase the concentrations of $\mathrm{Ni}$ and $\mathrm{Zn}$ in soils. The concentrations of $\mathrm{Ni}$ and $\mathrm{Zn}$ in sites $\mathrm{A}$ and $\mathrm{B}$ exceed the background values (23.8 and $59.8 \mathrm{mg} \cdot \mathrm{kg}^{-1}$, respectively) in this study, and no concentrations exceed the risk screening values (100 and $250 \mathrm{mg} \cdot \mathrm{kg}^{-1}$, respectively) in site B. Relevant studies have shown that the source of $\mathrm{Zn}$ is mainly related to frequent traffic, and the concentrations of Ni may not be affected by industrial activities [29]. Nonetheless, if the concentration of $\mathrm{Ni}$ exceeds the standard in soil, people may come into contact with Ni by eating food contaminated with it, of which soybeans, nuts, and oats contain high Ni.

With As mainly used in the pharmaceutical industry and in the preparation of insecticides and pesticides, it is a persistent toxicant due to its extremely high content in the pharmaceutical industry $[9,33,46$, 54]. The concentration of As has higher values than background values $\left(8.8 \mathrm{mg} \cdot \mathrm{kg}^{-1}\right)$, but the risk screening value $\left(30 \mathrm{mg} \cdot \mathrm{kg}^{-1}\right)$ is not exceeded in sites $\mathrm{A}$ and $\mathrm{B}$. The concentrations of As are $97.06 \%$ and $72.22 \%$ over the background value in the two regions. This result shows that As has a certain concentration in the natural environment of soil. In related studies, As also exceeds soil quality values in other regions and has a certain relationship with pollution emissions $[44,49,52,55$, $56]$.

In contrast to other metals, $\mathrm{Hg}$ has low concentrations in soil, but $\mathrm{Hg}$ indeed causes high pollution. Industrial production processes contribute to the concentration of $\mathrm{Hg}$, which will cause serious pollution to the environment. The excess rate in background value $\left(0.04 \mathrm{mg} \cdot \mathrm{kg}^{-1}\right)$ of $\mathrm{Hg}(55.56 \%)$ in site $\mathrm{B}$ is three times that in site $\mathrm{A}(14.71 \%)$. However, $\mathrm{Hg}$ concentrations do not exceed local risk screening values $\left(2.4 \mathrm{mg} \cdot \mathrm{kg}^{-1}\right)$. A major source of $\mathrm{Hg}$ in soil is the combustion of fossil fuels, especially coal combustion, which has become the largest source in all countries [57]. Nanos et al. presented that $\mathrm{Hg}$ concentrations can be used as indicators of industrial production and fuel consumption. This condition shows that $\mathrm{Hg}$ considerably pollutes the environment [58].

The concentrations of $\mathrm{Cu}$ are stable, but only some spots exceed the risk screening value. The concentrations of $41.18 \%$ and $27.78 \%$ exceed the background value $\left(19.8 \mathrm{mg} \cdot \mathrm{kg}^{-1}\right)$ and $2.94 \%$ and $5.56 \%$ exceed the risk screening value $\left(100 \mathrm{mg} \cdot \mathrm{kg}^{-1}\right)$ in sites A and $\mathrm{B}$, respectively. $\mathrm{Cu}$ is released into the environment due to improper handling of car batteries and leakage of car diesel and engine oil. Paint spraying, metal manufacturing of automobile parts, and burning of automobile tires, plastics, and other wastes also release metal pollutants into the atmosphere [58-59]. Some heavy metals have a negative impact on the population, other organisms, and environment of an area. Nartey et al. found by studying the spatial distribution of heavy metals in surface sediments of Sakumo Lagoon, Ghana that the high metal content may be due to the point source discharge of industrial and municipal wastewater [59]. This high content may come from a highly dense coastal population, in which residents drain waste into the sea [60].

The concentrations of the eight heavy metals in soil are different and present varying excess rates in background and risk screening values. Heavy metal concentrations also exceed local background values to varying degrees in other areas. As demonstrated by Liu et al., approximately $90 \%$ of six heavy metals $(\mathrm{Cd}, \mathrm{Cr}, \mathrm{As}, \mathrm{Pb}, \mathrm{Cu}$, and $\mathrm{Zn}$ ), especially $\mathrm{Cd}$, As, and $\mathrm{Zn}$, exceed the background values in local study areas [44]. Gao et al. indicated that all detected samples with As did not exceed the standard values, whereas $100 \%$, $100 \%, 100 \%, 57.14 \%, 50 \%, 57.14 \%$, and $42.86 \%$ of samples detected with $\mathrm{Pb}, \mathrm{Zn}, \mathrm{Cr}, \mathrm{Hg}, \mathrm{Cu}, \mathrm{Cd}$, and $\mathrm{Ni}$, respectively, exceeded the standard values in Baosteel of Shanghai [48]. The concentrations of heavy metals in surface soils are mainly due to human impacts. Jiao et al. also emphasized that some pollution may be caused by human activities, such as smelting plants and sewage irrigation [61]. Heavy metal availability was assessed on vineyard polluted soils. The results showed that the human contribution of $\mathrm{Cu}$ is obvious, that of 
Table 2. Correlation coefficient matrix between $\mathrm{Cd}, \mathrm{Pb}, \mathrm{Cr}, \mathrm{Cu}, \mathrm{Ni}, \mathrm{Zn}, \mathrm{As}$ and $\mathrm{Hg}$ in Site A and Site B.

\begin{tabular}{|c|c|c|c|c|c|c|c|c|}
\hline \multicolumn{7}{|c|}{ Site A } & As & Hg \\
\hline Classification & $\mathrm{Cd}$ & $\mathrm{Pb}$ & $\mathrm{Cr}$ & $\mathrm{Cu}$ & $\mathrm{Ni}$ & $\mathrm{Zn}$ & & \\
\hline $\mathrm{Cd}$ & 1.00 & & & & & & & \\
\hline $\mathrm{Pb}$ & $\mathbf{- 0 . 3 8 4 *}$ & 1.00 & & & & & & \\
\hline $\mathrm{Cr}$ & 0.071 & 0.442 & 1.00 & & & & & \\
\hline $\mathrm{Cu}$ & 0.248 & 0.005 & -0.044 & 1.00 & & & & \\
\hline $\mathrm{Ni}$ & 0.322 & -0.166 & $\mathbf{0 . 4 5 3 * *}$ & 0.077 & 1.00 & & & \\
\hline $\mathrm{Zn}$ & -0.093 & $\mathbf{0 . 3 7 4}$ & -0.015 & 0.126 & 0.040 & 1.00 & & \\
\hline $\mathrm{As}$ & -0.205 & 0.032 & -0.197 & -0.291 & -0.055 & -0.050 & 1.00 & \\
\hline $\mathrm{Hg}$ & -0.030 & -0.185 & -0.325 & -0.075 & -0.068 & -0.028 & 0.038 & 1.00 \\
\hline
\end{tabular}

\begin{tabular}{|c|c|c|c|c|c|c|c|c|}
\hline \multicolumn{9}{|c|}{ Site B } \\
\hline Classification & $\mathrm{Cd}$ & $\mathrm{Pb}$ & $\mathrm{Cr}$ & $\mathrm{Cu}$ & $\mathrm{Ni}$ & $\mathrm{Zn}$ & As & $\mathrm{Hg}$ \\
\hline $\mathrm{Cd}$ & 1.00 & & & & & & & \\
\hline $\mathrm{Pb}$ & 0.444 & 1.00 & & & & & & \\
\hline $\mathrm{Cr}$ & 0.125 & 0.167 & 1.00 & & & & & \\
\hline $\mathrm{Cu}$ & $0.694 * *$ & $0.717 * *$ & 0.215 & 1.00 & & & & \\
\hline $\mathrm{Ni}$ & -0.058 & 0.071 & $0.764 * *$ & 0.245 & 1.00 & & & \\
\hline $\mathrm{Zn}$ & 0.056 & 0.106 & -0.017 & 0.196 & 0.039 & 1.00 & & \\
\hline As & $0.573 *$ & -0.193 & -0.293 & 0.204 & -0.311 & 0.021 & 1.00 & \\
\hline $\mathrm{Hg}$ & $0.772 * *$ & $0.669 * *$ & -0.153 & $0.806 * *$ & -0.320 & 0.088 & 0.409 & 1.00 \\
\hline
\end{tabular}

$*$ is a significant level of $0.05 ; * *$ is a significant level of 0.01

$\mathrm{Pb}$ is from external pollution sources, and that of $\mathrm{As}$ and $\mathrm{Zn}$ is insignificant [62-63]. If the concentration of heavy metals exceeds the local risk screening value, human intervention is necessary, and relevant protection policies for pollution prevention and control should be formulated.

\section{Source Analysis}

\section{Correlation Analysis}

In this study, the relationship between different heavy metals in sites A and B is investigated via correlation analysis in accordance with the concentration of heavy metals in surface soil. The correlation coefficient matrix obtained using the concentration of each heavy metal is listed in Table 2 to observe the correlation intensity among heavy metals accurately.

In site $\mathrm{A}$, the correlation coefficient of $\mathrm{Cr}$ and $\mathrm{Ni}$ $\left(0.453^{* *}\right)$ indicates that $\mathrm{Cr}$ and $\mathrm{Ni}$ come from the same source. This trend is the same with $\mathrm{Cr}$ and $\mathrm{Ni}\left(0.764^{* *}\right)$ in site $\mathrm{B}$. For the three metals of $\mathrm{Cd}, \mathrm{Pb}$, and $\mathrm{Zn}$, the correlation coefficients of $\mathrm{Cd}$ and $\mathrm{Pb}$ and $\mathrm{Pb}$ and $\mathrm{Zn}$ are - 0.384* and 0.374*, respectively. Therefore, $\mathrm{Cd}$ has an opposite impact on $\mathrm{Pb}$ and $\mathrm{Zn}$, implying that $\mathrm{Cd}, \mathrm{Pb}$, and $\mathrm{Zn}$ may come from an identical source in site A.
This result is similar to that in Klake. A high positive correlation exists between $\mathrm{Zn}$ and $\mathrm{Pb}$ concentrations in Sakumo and Kpeshie lagoon sediments [62]. An insignificant difference exists in the levels of $\mathrm{Zn}, \mathrm{Pb}$, and $\mathrm{Cd}$ in consideration of the concentration range, population mean, and error amplitude. In site $\mathrm{B}$, the correlation coefficients of $\mathrm{Cd} \& \mathrm{Cu}$ and $\mathrm{Cd} \& \mathrm{Hg}$ are $0.694 * *$ and $0.772 * *, \mathrm{~Pb} \& \mathrm{Cu}$ and $\mathrm{Pb} \& \mathrm{Hg}$ are $0.717 * *$ and $0.669^{* *}$, and $\mathrm{Cu}$ and $\mathrm{Hg}$ are $0.806^{* *}$, respectively, which all show extremely strong correlations. Thus, $\mathrm{Cd}, \mathrm{Pb}, \mathrm{Cu}$, and $\mathrm{Hg}$ may come from the same source in site $\mathrm{B}$.

\section{Hierarchical Cluster Analysis (HCA)}

HCA of heavy metals is conducted to judge the results of the correlation analysis of heavy metal species from the same source. The result of $\mathrm{HCA}$ of $\mathrm{Cd}, \mathrm{Pb}, \mathrm{Cr}$, $\mathrm{Cu}, \mathrm{Ni}, \mathrm{Zn}, \mathrm{As}$, and $\mathrm{Hg}$ in sites $\mathrm{A}$ and $\mathrm{B}$ is shown in Fig. S1.

Four classifications, namely, A1 ( $\mathrm{Ni}-\mathrm{Zn}-\mathrm{Hg}-$ $\mathrm{Cr}), \mathrm{A} 2(\mathrm{Cd}), \mathrm{A} 3(\mathrm{~Pb}-\mathrm{Cu})$, and $\mathrm{A} 4(\mathrm{As})$, in site $\mathrm{A}$ are established. Consistent with the correlation analysis, $\mathrm{Cr}$ and $\mathrm{Ni}$ come from the same source, and A2 exerts an opposite effect on A1 and A3. The source of different heavy metals is not decided by one or some elements 
but by various human actions. Finding a crucial pathway for the classification result is possible. First, the four metals of $\mathrm{Ni}, \mathrm{Zn}, \mathrm{Hg}$, and $\mathrm{Cr}$ are the main components of diesel, gasoline, and van batteries. Several products require transportation to be sold. $\mathrm{A} 1(\mathrm{Ni}-\mathrm{Zn}-\mathrm{Hg}-$ $\mathrm{Cr}$ ) is attributed to industrial transportation, road traffic, automobile tire friction, and tank leakage. Khalilova et al. indicated that transport emissions largely lead to heavy metal pollution in the Peninsula ecosystem [52]. Second, Cd has a high content in site $\mathrm{A}$, and industrial waste has a great contribution to $\mathrm{Cd}$ pollution. A2 (Cd) is mainly caused by industrial sewage and waste discharge, especially in industrial areas where AI and $\mathrm{LI}$ are distributed. Third, $\mathrm{A} 3(\mathrm{~Pb}-\mathrm{Cu})$ has a certain content in the crust, combining local geographical characteristics. CI and GM (a, b) are the main sources, and the metal smelting industries contain high levels of ore, emitting dust of $\mathrm{Pb}$ and $\mathrm{Cu}$. Lastly, As is not combined with other metals. Substantial agricultural land exists around factories, which is also considered one of the sources of pesticides and fertilizers used in agricultural production. As has been enriched in surface soils from agricultural activities for a long time. Farmland accounts for a large proportion of the land in the study area, and sewage irrigation has a long history, which may be the reason why heavy metal pollution is mainly distributed in farmland [61]. In site B, the four classifications shown in the analysis are $\mathrm{B} 1(\mathrm{Cu}-\mathrm{Hg}$ $-\mathrm{Pb}-\mathrm{Cd}), \mathrm{B} 2(\mathrm{Cr}), \mathrm{B} 3$ (Ni - Zn), and B4 (As). They are basically consistent with the results of the previous correlation analysis, showing a strong correlation and confirming that they come from the same source. $\mathrm{Cr}$ and As are divided, which may be related to industrial species within the region.

The close production of the industrial system around farmland has led to the local transportation industry, but it is unfavorable to agricultural production, crop growth, artificial large-scale agricultural cultivation, and other activities. This condition accelerates the migration of ore powder dust. The sources of heavy metals vary and are mainly related to local industrial types, traffic distribution, and agricultural activities. For example, Bayrakli et al. exhibited that $\mathrm{Cu}, \mathrm{Cd}$, and $\mathrm{Pb}$ levels also increased slightly in some parts of the study area, possibly due to anthropogenic effects, such as excess fertilizer, field traffic, and pesticide use [63]. Khalilova et al. found $\mathrm{Pb}$ and $\mathrm{Cr}$ in soils in transport road areas. The burning of petroleum products at transport facilities is a major source of environmental pollution caused by these metals [52]. Different heavy metals not only have one fixed source, but also one of the sources can promote the concentration of heavy metals obviously. Among many sources, human activities increase the pollution of heavy metals in natural environment. The fundamental way to decrease heavy metal pollution is to reduce human interference effectively, such as limiting the excessive use of pesticides and chemical fertilizers and the discharge of industrial wastewater after reaching the standard value.

\section{Principal Component Analysis (PCA)}

PCA is a multivariate statistical method to investigate the correlation among different heavy metals and study how to reveal the internal structure among multiple variables through a few principal components. The results of PCA in sites $\mathrm{A}$ and $\mathrm{B}$, including three component factors and two component factors, are shown in Fig. S2. PC1 accounts for $22.85 \%$ of the contribution rate for site $\mathrm{A}$. The positive contribution is mainly from $\mathrm{Cd}(0.711) \approx \mathrm{Ni}(0.707)$ and $\mathrm{Cr}(0.442)$ $\approx \mathrm{Cu}(0.461)$, and the negative contribution is mainly from $\mathrm{Pb}(-0.416)$, As $(-0.435)$, and $\mathrm{Hg}(-0.225)$ in PC1. PC2 accounts for $21.11 \%$, showing more prominent $\mathrm{Pb}$ (0.747), Zn (0.611), Cr (0.582), and $\mathrm{Hg}(-0.513)$ compared with the results given by $\mathrm{PC} 1$ and indicating that they may be due to transportation, not industrial pollution. $\mathrm{Zn} \mathrm{(0.396)}$ and $\mathrm{Cu}(0.649)$ dominate the overall rate of change for $\mathrm{PC} 3$. The overall contribution rate is only $17.29 \%$, which is considered to be due to the use of fertilizers and pesticides in agricultural activities. For site $\mathrm{B}, \mathrm{PCl}$ has $40.22 \%$ contribution rate, including $\mathrm{Cd}$ (0.875), $\mathrm{Pb}$ (0.723), $\mathrm{Cu}$ (0.901), and $\mathrm{Hg}$ (0.945). They have a high decision-making effect on $\mathrm{PCl}$ and high coefficients. This result is fully consistent with the results discussed above in site $\mathrm{B}$, confirming that $\mathrm{Cd}$, $\mathrm{Pb}, \mathrm{Cu}$, and $\mathrm{Hg}$ originate from the same sources. The overall rate of change is $26.69 \%$ in PC2 and $13.39 \%$ in PC3. The dominant metals are $\mathrm{Cr}(0.873)$ and $\mathrm{Ni}(0.891)$ in $\mathrm{PC} 2$ and $\mathrm{As}(0.600), \mathrm{Cd}(0.347) \approx \mathrm{Cr}(0.327)$, and $\mathrm{Pb}$ $(-0.467)$ in $\mathrm{PC} 3$. The industrial systems in site $\mathrm{B}$ are denser relative to site $\mathrm{A}$. Hence, the four heavy metals of $\mathrm{Cd}, \mathrm{Pb}, \mathrm{Cu}$, and $\mathrm{Hg}$ from the same source should be considered emphatically. $\mathrm{Cd}, \mathrm{Pb}, \mathrm{Cu}$, and $\mathrm{Hg}$ have a great impact on the pollution in site $\mathrm{B}$, which may be due to the wastewater from the same source or ore mining. This results needs to be verified and solved as soon as possible.

The cluster effect of heavy metals in site B is more obvious than that in site A in accordance with Fig. S2. The number of industries in site $B$ is less than that in site $\mathrm{A}$, but the degree of industry distribution is stronger. Especially in site $\mathrm{B}$, the four metals of $\mathrm{Pb}, \mathrm{Cu}$, $\mathrm{Cr}$, and $\mathrm{Hg}$ may combine because of the small number of industries. These four metals should be given priority in the prevention and control in site B. Meanwhile, the influence of metals in site A tends to be dispersed and not as concentrated as that in site B. The reason is that industry distribution is disperse; consequently, the region controlling measure toward heavy metals should be carried out from the beginning of every industry.

\section{Potential Ecological and Health Risk Assessment Index of Geoaccumulation ( $\mathrm{I}_{\mathrm{geo}}$ )}

For local industrial areas, Igeo values of different heavy metals in sites A and B are calculated and displayed in Fig. 4. The levels of contamination of metals in both sites are the same. Of the eight heavy metals, 


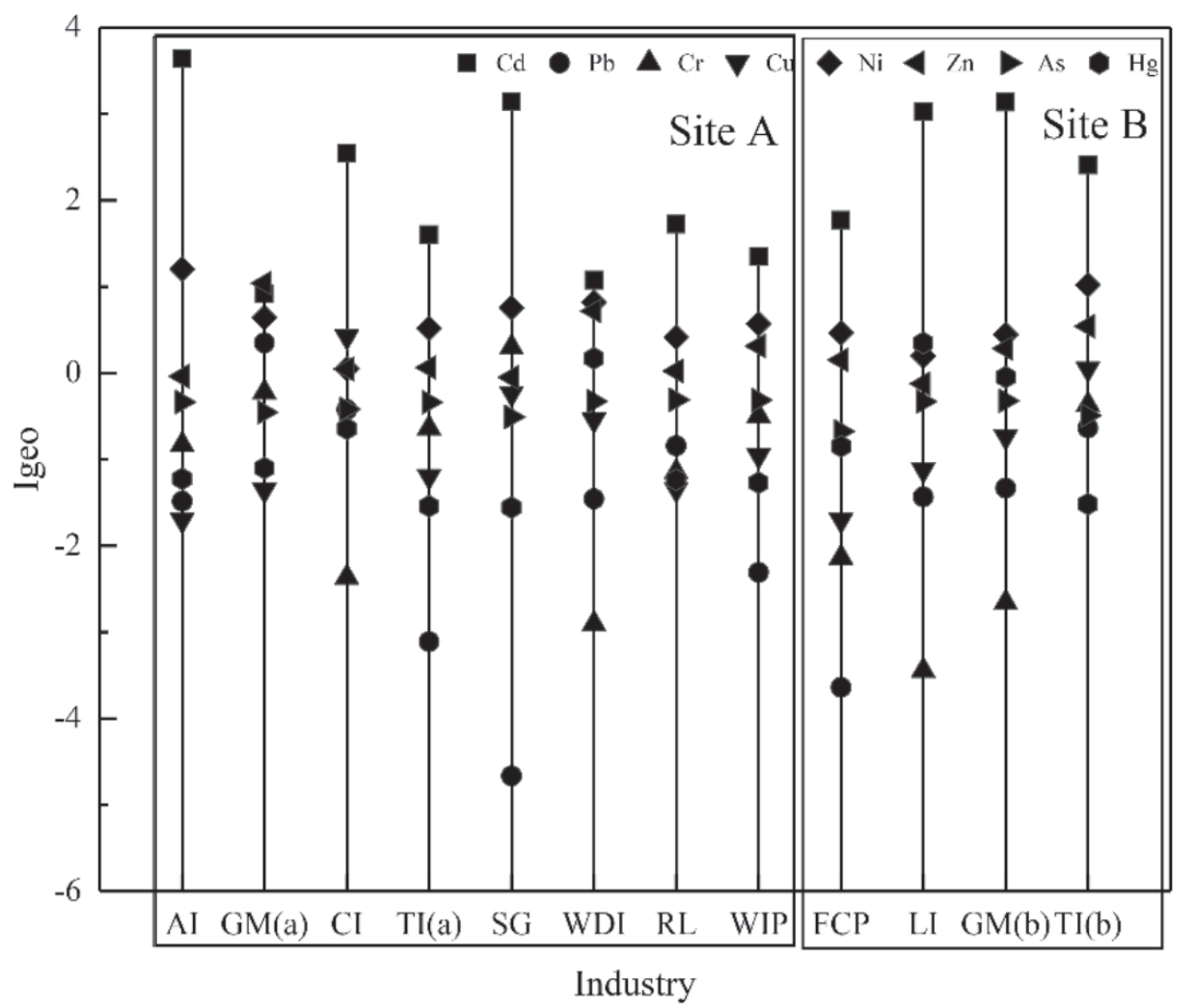

Fig. 4. The distribution of Igeo values for $\mathrm{Cd}, \mathrm{Pb}, \mathrm{Cr}, \mathrm{Cu}, \mathrm{Ni}, \mathrm{Zn}, \mathrm{As}$ and $\mathrm{Hg}$ in Site A and Site B (site A is left, site B is right).

$\mathrm{Cd}$ has more serious pollution levels in the two regions. Igeo value of $\mathrm{Cd}$ is mainly between 1 and 4 , which is in the state of medium pollution level or transition to heavy pollution level. Ni has higher concentration contents in the two regions than the background value, and it is in the transition state of uncontaminated to moderate pollution. $\mathrm{Zn}$ has Igeo value between 0 and 1 , with slight contamination. The five metals of $\mathrm{Pb}, \mathrm{Cr}$, $\mathrm{Cu}$, As, and $\mathrm{Hg}$ are in an unpolluted level. This result is basically consistent with the finding of Liu et al.. Cd was found to be the most serious pollutant in industrial areas, whereas $\mathrm{Zn}$ indicates a minimal pollution level in the study area. However, Zakir et al. found that $\mathrm{Cd}$, $\mathrm{Pb}$, and $\mathrm{Zn}$ have moderate pollution levels through the study of heavy metal pollution in Gazipur district, and these metals are mainly from human sources of different industrial activities [53]. Similarly, Li et al. indicated that the ecological risks of the five major heavy metals are in the order of $\mathrm{Cu}>\mathrm{Zn}>\mathrm{Cd}>\mathrm{Pb}>\mathrm{Hg}$ [69]. The coastal areas for shellfish culture in China are seriously polluted by heavy metals. The river body of Kemalpasa district center and its neighborhood were researched. The river is heavily polluted by the industrial areas of metal processing, food and beverage production, marble and natural stone production, and paper production [64]. Therefore, different sources of heavy metals have varying pollution levels. However, human actions, agricultural activities, and industrial production play a major role.

\section{Potential Ecological Assessment}

Ecological risk assessment considers not only the human factors that cause heavy metal accumulation in soil from industrialization but also the biological toxicity of different elements [32-33, 61]. Some Er value distributions of $\mathrm{Cd}, \mathrm{Pb}, \mathrm{Cr}, \mathrm{Cu}, \mathrm{Ni}, \mathrm{Zn}, \mathrm{As}$, and $\mathrm{Hg}$ in sites $\mathrm{A}$ and $\mathrm{B}$ are shown in Fig. 5. The RI value of all samples is calculated, as shown in Fig. 6.

The value of $\mathrm{Er}$ for $\mathrm{Cd}$ is significantly higher than that for the seven other heavy metals, mainly because the concentration of $\mathrm{Cd}$ in soil is higher than the background value to a great extent. The pollution degree of Cd from AI, CI, SG, LI, GM (b), and TI (b) has reached the medium risk degree and has a high contribution rate to the value of RI. The heavy metals of $\mathrm{Pb}, \mathrm{Cr}, \mathrm{Cu}, \mathrm{Ni}, \mathrm{Zn}$, and As present a low risk. This result means that the metals have some contents in industrial soils but they do not present serious risk. However, the $\mathrm{Hg}$ concentration from $\mathrm{CI}$ and $\mathrm{GM}$ (b) reaches the middle risk level, even the contents from WDI and LI indicate a considerable risk degree. Evident differences in the pollution degree of different industries are determined, in which $\mathrm{Cd}$ and $\mathrm{Hg}$ have a large contribution rate. This finding is consistent with the results of relevant studies. For example, Pan et al. studied the distribution characteristics of heavy metals near a smelter in Shanxi province [16]. The author found that the area is highly contaminated by $\mathrm{Cd}$ and $\mathrm{Hg}$, suggesting possible ecological hazards. In 


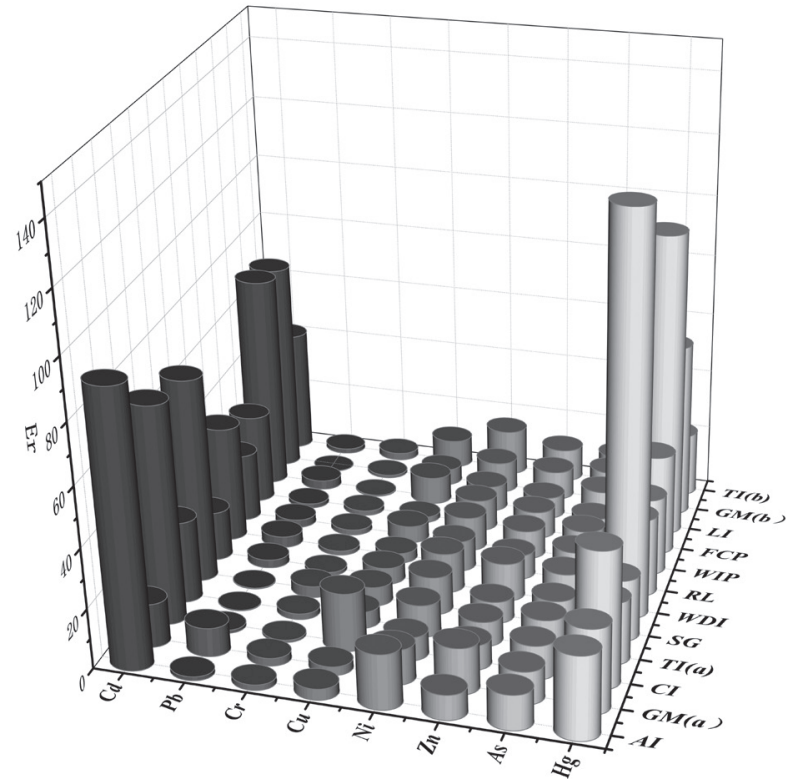

Fig. 5. Potential ecological risk assessment of Er values of $\mathrm{Cd}$, $\mathrm{Pb}, \mathrm{Cr}, \mathrm{Cu}, \mathrm{Ni}, \mathrm{Zn}, \mathrm{As}$ and $\mathrm{Hg}$ around different industrial areas.

soils of other megacities, such as Rome and Mexico, $\mathrm{Cd}$ and $\mathrm{Hg}$ also present a much higher risk than other elements for potential ecosystem health [66]. A similar conclusion was drawn from studies by Chen et al., that is, $\mathrm{Cd}$ and $\mathrm{Hg}$ mainly cause heavy metals in soils to pollute urban areas [14]. Especially, Cheng's study [43] in the southern part of Hubei province is completely consistent with the results of the current study. Cd and $\mathrm{Hg}$ have high potential ecological risks and large coefficients of change, whereas $\mathrm{Pb}, \mathrm{Cr}, \mathrm{Cu}, \mathrm{Ni}, \mathrm{Zn}$, and As have low potential ecological risks. In particular, the rapid growth of industry and population has caused important environmental problems in many industrial areas worldwide. On the basis of RI value in Fig. 6, AI, CI, WDI, LI, and GM (b) reach a moderate risk degree, and other industries are in a low risk degree. Although the risk value of heavy metals around industries is higher in site A than in site B, the total area of site A is in a low risk degree and that of site $\mathrm{B}$ is in a moderate risk degree. The pollution from $\mathrm{Cd}$ and $\mathrm{Hg}$ in site $\mathrm{B}$ is sharply serious than that in site A. This phenomenon is also affected by some of the surrounding agricultural activities, which should involve the development of protective measure and pollution prevention.

\section{Potential Health Assessment}

For the metals of $\mathrm{Cd}, \mathrm{Cr}, \mathrm{Ni}, \mathrm{Zn}, \mathrm{As}$, and $\mathrm{Hg}$ in sites $\mathrm{A}$ and $\mathrm{B}$, the noncancer risk of $\mathrm{HI}$ values is listed in Table S7. HI value in site A (that for children is $8.58 \mathrm{E}-$ 01 , and that for adult is 1.02E-01) is higher than that in site B (that for children is 4.17E-01, and that for adult is 4.85E-02). HI values of different industries are similar. The number of industries in site $\mathrm{A}$ is more than that in site $\mathrm{B}$. The noncancer risk in children is significantly higher than that in adults for $\mathrm{As}>\mathrm{Ni}>\mathrm{Cd}>\mathrm{Zn}>\mathrm{Hg}>\mathrm{Cr}$ in the two areas.

In site $\mathrm{A}$, the top three industries in terms of contribution rate are $\mathrm{AI}$, WDI, and $\mathrm{SG}$, their $\mathrm{HI}$ values are 1.50E-01 (children) and 1.74E-02 (adult),

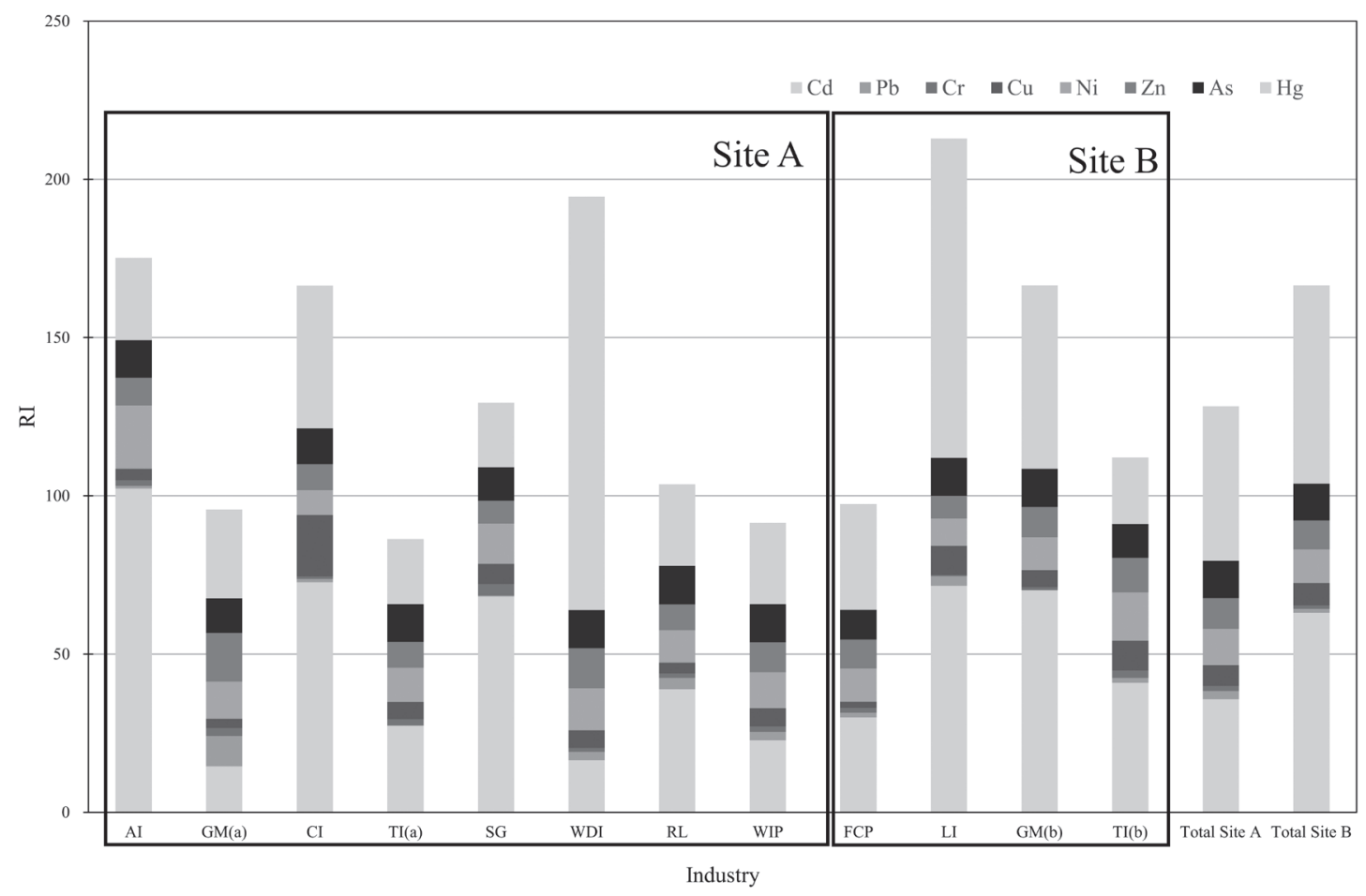

Fig. 6. Potential ecological risk assessment of RI values of different industries in Site A and Site B. 
1.10E-01 (children) and 1.41E-02 (adult), and 1.11E01 (children) and 1.28E-02 (adult), respectively. In the three industries, $\mathrm{Ni}$ and As play an important role in $\mathrm{HI}$ values of children and adults. That is, $\mathrm{Ni}$ and As from the three mentioned industries present a noncancer risk influence on children and adults. Heavy metals have different pathways of entering into the human body. The five metals of $\mathrm{Cd}, \mathrm{Ni}, \mathrm{Zn}, \mathrm{As}$, and $\mathrm{Hg}$ mainly enter the human body via ingestion $>$ dermal contact $>$ inhalation, and $\mathrm{Cr}$ enters via inhalation $>$ ingestion $>$ dermal contact. This result suggests that local people should avoid eating vegetables and fruits from the agricultural land around industries and that residents should stay off the road to avoid inhalation of $\mathrm{Cr}$. Although HI values do not exceed the edge value, indicating that they do not pose a strong threat to the human body, attention should also be paid. HI value of site A for children is $8.58 \mathrm{E}-01$, which is a high value within the scope of risk. Measures need to be taken to prevent noncancer risk in children. In accordance with the use of a vitro digestion model in assessing the bioavailability of heavy metals in rice, combined with heavy metal exposure, the total risk factor (HQ) of adults is higher than the acceptable range $(\mathrm{HQ}<1)$; meanwhile, the total lifetime cancer risk of adults and children is higher than the acceptable range [67]. Zhang et al. emphasized that dietary intake is the main way of exposure. In all factors, the distance from industrial enterprises, altitude, soil $\mathrm{pH}$ value, and the distance from main roads are the most influential ones $[33,68]$.

In site $\mathrm{B}$, the three industries of $\mathrm{LI}, \mathrm{TI}(\mathrm{b})$, and $\mathrm{GI}(\mathrm{b})$ have higher noncancer risk than FCP; their HI values are 1.07E-01 (children) and 1.19E-02 (adult), 1.11E-01 (children) and 1.26E-02 (adult), and 1.12E-01 (children) and 1.35E-02 (adult), respectively. The main metals from these industries are $\mathrm{Ni}$ and As, and this situation is similar to site A. Different regions are divided, but this division does not change the crucial factor of $\mathrm{Ni}$ and As. Various metals, expect for $\mathrm{Cr}$, still enter into the human body via the pathway of ingestion. This situation is related to the same industry attributes in sites A and B, such as GM(a) \& GM(b) and TI (a) \& TI(b), but the noncancer risk is different between the two sites. For GM, HI values of children and adults from $\mathrm{Cd}, \mathrm{As}$, and $\mathrm{Hg}$ in site $\mathrm{A}$ are higher than those in site B. On the contrary, HI values of children and adults from $\mathrm{Cr}, \mathrm{Ni}$, and $\mathrm{Zn}$ in site $\mathrm{B}$ are higher than those in site A. The noncancer risk caused by different metals also applies to children and adults around TI. Noncarcinogenic risks from $\mathrm{Cd}, \mathrm{Cr}, \mathrm{Ni}, \mathrm{Zn}, \mathrm{As}$, and $\mathrm{Hg}$ in site $\mathrm{B}$ are more than those in site A, but that from As presents the opposite result. The preceding discussion shows that heavy metals come from different sources, but industry distribution is an influential factor to the concentration of heavy metals [69]. This finding is well documented in the difference in noncancer risk between the same industry types. The concentration difference of heavy metals is the origin of different noncancer risks.
$\mathrm{CR}$ value of cancer risk of $\mathrm{Cr}, \mathrm{Ni}$, and $\mathrm{As}$ is analyzed in Table S8. The cancer risk in entire site A (that in children is $2.13 \mathrm{E}-03$, and that in adult is $1.08 \mathrm{E}-$ 03 ) is higher than that in entire site B (that in children is 9.19E-04, and that in adult is 4.64E-04), and the cancer risk values of heavy metals are in the following order: $\mathrm{Ni}>\mathrm{Cr}>\mathrm{As}$. The considerable industries in site A cause the high expose of the human body to cancer risk. The exposure pathway of $\mathrm{Ni}$ and $\mathrm{As}$ is ingestion, whereas that of $\mathrm{Cr}$ is dermal contact in sites $\mathrm{A}$ and $\mathrm{B}$. The cancer risk of $\mathrm{Cr}$ from SG is $1.24 \mathrm{E}-04$ in children, which is an unaccepted value. $\mathrm{Ni}$ is a threat metal to humans in sites A and B, especially for children. For $\mathrm{Ni}$, the different industries of AI, GM (a), CI, TI (a), SG, WDI, RL FCP, LI, GM (b), and TI (b) cause the possibility of cancer to children, and their $\mathrm{CR}$ values are $3.02 \mathrm{E}-04,1.76 \mathrm{E}-04,1.18 \mathrm{E}-04,1.63 \mathrm{E}-04,1.91 \mathrm{E}-$ $04,2.00 \mathrm{E}-04,1.55 \mathrm{E}-04,1.58 \mathrm{E}-04,1.30 \mathrm{E}-04,1.56 \mathrm{E}-$ 04, and 2.29E-04, respectively. Cancer risk from As to children and adults in sites A and B is also determined. The concentrations of $\mathrm{Ni}$ should be controlled as soon as possible, and $\mathrm{CR}$ values of children in the two areas should also be focused on. Most of $\mathrm{Cr}$ and all of $\mathrm{Ni}$ are in an acceptable range for the population within that range, and no great threat to human health is identified.

\section{Conclusions}

The sources of eight different heavy metals were analyzed by examining surface soil samples around industries. The heavy metals in sites A and B were also evaluated for potential ecological and health risk assessment. The following conclusions were drawn.

The concentrations of $\mathrm{Cd}, \mathrm{Pb}, \mathrm{Cr}, \mathrm{Cu}, \mathrm{Ni}, \mathrm{Zn}, \mathrm{As}$, and $\mathrm{Hg}$ exceeded the background value to varying degrees, indicating that these metals, especially $\mathrm{Cd}$, were enriched in the surface soil of the study area. Human activities play an important role in heavy metal pollution; meanwhile, the source of heavy metals differs with the development of human life. They mainly come from transportation, industrial sewage and waste emission, geographical characteristics, and pesticide and fertilizer use. The number of industries in site $\mathrm{A}$ is more than that in site $\mathrm{B}$, but site $\mathrm{A}$ only reaches a low risk degree. On the contrary, site $\mathrm{B}$ reaches a medium risk degree. AI, CI, and WDI have medium risks in site A, and LI and GM (b) cause relatively great pollution in site B. Related control and measure should be drawn up from noncancer and cancer risks.

\section{Acknowledgments}

This work was funded by General Project for Scientific Research of Liaoning Provincial Education Department (LJ2019JL029), the National Natural Science Foundation of China (No. 41501548, 41807384), the China Postdoctoral Science Foundation (No. 
2018M630304), and LiaoNing Revitalization Talents Program (XLYC1807056, XLYC1908013), Basic Research Project of Colleges and Universities in Liaoning Province (LJ2017QL015, LJ2017QL016).

\section{Conflict of Interest}

The authors declare no conflict of interest.

\section{References}

1. RAVANKHAH N., MIRZAEI R., MASOUM S. Spatial Eco-Risk Assessment of Heavy Metals in the Surface Soils of Industrial City of Aran-o-Bidgol, Iran. Bulletin of Environmental Contamination and Toxicology 96 (4), 516, 2016.

2. LUO Q., SHAN Y., MUHAMMAD A. Levels, distribution, and sources of organophosphate flame retardants and plasticizers in urban soils from Shenyang, China. Environmental Science and Pollution Research 25, 31752, 2018.

3. LUO Q., GU L.Y., WU Z.P., SHAN Y., WANG H., SUN L.N. Distribution, source apportionment and ecological risks of organophosphate esters in surface sediments from the Liao River, Northeast China. Chemosphere 250, 126297, 2020.

4. LUO Q., GU L.Y., SHAN Y., SUN L.N. Distribution, source apportionment and health risk assessment of polycyclic aromatic hydrocarbons in urban soils from Shenyang, China. Environmental Geochemistry and Health 42, 1817, 2020.

5. CHOWDHURY S., JAFER MAZUMDER M.A., ALATTAS O., HUSAIN T. Heavy metals in drinking water: occurrences, implications, and future needs in developing countries. Science of the Total Environment 569-570, 476, 2016.

6. OVES M., KHAN M.S., ZAIDI A., AHMAD E. Soil contamination, nutritive value, and human health risk assessment of heavy metals: an overview. Tox. Toxicity of Heavy Metals to Legumes and Bioremediation 1, 1, 2012.

7. PRAVEENA S.M., PRADHAN B., ISMAIL S.N.S. Spatial assessment of heavy metals in surface soil from Klang District (Malaysia): an example from a tropical environment. Human and Ecological Risk Assessment 21 (7-8), 1980, 2015.

8. KHAN S., MUNIR S., SAJJAD M., LI G. Urban park soil contamination by potentially harmful elements and human health risk in Peshawar City, Khyber Pakhtunkhwa, Pakistan. Journal of Geochemical Exploration 165, 101, 2016.

9. ADINA C.B., BERNADETTE O.N., GUNNAR O.S., SVEN E.K., LOUWRENS C.H. Heavy metals in marine fish meat and consumer health: a review. Journal of Agricultural and Food Chemistry 96, 32, 2012.

10. WCISLO E., BRONDER J., BUBAK A., RODRIGUEZVALDES E., GALLEGO JLR. Human health risk in restoring safe and productive use of abandoned contaminated sites. Environment International 94, 436, 2016.

11. GERVASIO A.L., ANA N.A., DANIEL B.M., KERRY L.L. Heavy metals, cardiovascular disease, and the un assessment expected benefits of chelation therapy. Journal of the American College of Cardiology 67, 2411, 2016.

12. MA Y., EGODAWATTA P., MCGREE J., LIU A., GOONETILLEKE A. Human health risk assessment of heavy metals in urban stormwater. Science of the Total Environment 557, 764, 2016.

13. SOCK Y.T., SARVA M.P., EMILIA Z.A., MANRAJ S.C. A review of heavy metals in indoor dust and its human health-risk implications. Reviews on Environmental Health 31, 447, 2016.

14. CHEN K., HUANG L., YAN B.Z., LI H.B., SUN H., BI J. Effect of lead pollution control on environmental and childhood blood lead level in nantong, china: an interventional study. Environmengtal Science Technology 21 (48), 12930, 2014.

15. ZHANG X.Y., ZHONG T.Y., LIU L., OUYANG X.Y. Impact of soil heavy metal pollution on food safety in China. PloS one 10, 13582, 2015.

16. PAN L.B., MA J., WANG X.L., HOU H. Heavy metals in soils from a typical county in shanxi province, china: levels, sources and spatial distribution. Chemosphere 148, 248, 2016.

17. WANG G.Y., ZHANG S.R., XIAO L.Y., et al. Heavy metals in soils from a typical industrial area in sichuan, china: spatial distribution, source identification, and ecological risk assessment. Environmental Science Pollution Research 24, 16618, 2017.

18. CHEN H.Y., TENG Y.G., LU S.J., WANG Y.Y., WANG J.S. Contamination features and health risk of soil heavy metals in China. Science of the Total Environment 512513, 143, 2015

19. GUO G.H., WU F.C., XIE F.Z., ZHANG R.Q. Spatial distribution and pollution assessment of heavy metals in urban soils from southwest China. Journal Environmental Sciences 3 (24), 410, 2012.

20. SHARAREH D., FARID M., BEHNAM K., BEVERLEY A.H. Health risk implications of potentially toxic metals in street dust and surface soil of Tehran, Iran. Ecotoxicology and Environmental Safety 136, 92, 2017.

21. MOORE F., SHEYKHI V., SALARI M., BAGHERI A. Soil quality assessment using GIS-based chemometric approach and pollution indices: Nakhlak mining district, Central Iran. Environmental Monitoring and Assessment 188, 214, 2016.

22. DUAN H.B., HU J.K., TAN Q.Y., LIU L.L., WANG Y.J., LI J.H. Systematic characterization of generation and management of e-waste in China. Environmental Science Pollution Research 23, 1929, 2016.

23. LI Z.Y., MA Z.W., VAN DER, KUIJP T.J., YUAN Z.W., HUANG L. A review of soil heavy metal pollution from mines in China: pollution and health risk assessment. Science of the Total Environment 468-469, 843, 2014.

24. XIA X.Q., LI G.C., YANG Z.F., YU T., HOU Q.Y. Practicability of monitoring soil $\mathrm{Cd}, \mathrm{Hg}$, and $\mathrm{Pb}$ pollution based on a geochemical survey in China. Chemosphere 172, 217, 2017.

25. ADELEKAN B.A., ABEGUNDE K.D. Heavy metals contamination of soil and groundwater at automobile mechanic villages in Ibadan, Nigeria. International Journal of Molecular Sciences 6, 1045, 2011.

26. SIU-LAN LEE C., LI X.D., SHI W.Z., CHEUNG S.C., THORNTON L. Metal contamination in urban, suburban, and country park soils of Hong Kong: a study based on GIS and multivariate statistics. Science of the Total Environment 356, 45, 2006. 
27. YANG Q.Q., LI Z.Y., LU X.N., DUAN Q.N., HUANG L., BI J. A review of soil heavy metal pollution from industrial and agricultural regions in China: Pollution and risk assessment. Science of the Total Environment 642, 690, 2018.

28. LI K.J., GU Y.S., LI M.Z. Spatial analysis, source identification and risk assessment of heavy metals in a coal mining area in Henan, Central China. International Biodeterioration and Biodegradation 128, 148, 2018.

29. WU W., WU P., YANG F., SUN D.L., ZHANG D.X., ZHOU Y.K. Assessment of heavy metal pollution and human health risks in urban soils around an electronics manufacturing facility. Science of the Total Environment 630, 53, 2018.

30. ISIMEKHAI K.A., GARELICK H., WATT J., PURCHASE D. Heavy metals distribution and risk assessment in soil from an informal E-waste recycling site in Lagos State, Nigeria. Environmental Science and Pollution Research 24, 17206, 2017.

31. MANMOHIT S., PARTEEK S.T., SIBY J. Health risk assessment of the workers exposed to the heavy metals in e-waste recycling sites of Chandigarh and Ludhiana, Punjab, India. Chemosphere 203, 426, 2018.

32. TANG J.X., HE M.M., LUO Q., ADEEL M. FENG J. Heavy Metals in Agricultural Soils from a Typical Mining City in China: Spatial Distribution, Source Apportionment, and Health Risk Assessment. Polish Journal of Environmental Studies 29, 1379, 2019.

33. ZHANG C.P., ZHENG Z.Y., YAO S.H., JIA H.L., XIAN X.N., WANG L. Ecological Risk of Heavy Metals in Sediment Around Techeng Island Special Marine Reserves in Zhanjiang Bay. Journal Ocean University of China 19, $561,2020$.

34. ZHANG M., WANG X.P., LIU C., et al. Identification of the heavy metal pollution sources in the rhizosphere soil of farmland irrigated by the Yellow River using PMF analysis combined with multiple analysis methods - using Zhongwei city, Ningxia, as an example. Environmental Science and Pollution Research 27, 16203, 2020.

35. Ministry of Ecology and Environment of the people's Republic of China. Soil environmental quality control standard for soil pollution risk of agricultural land (Trial) (GB15618-2018), 2018.

36. ELAHIA F., HEIDARI R., CHARGHAN V.R., ASADBEIK E., MIRZAEI S.A.E. Genetically modified Pichia pastoris, a powerful resistant factory for gold and palladium bioleaching and nanostructure heavy metal biosynthesis. Artificial Cells Nanomedicine and Biotechnology 48, 259, 2020.

37. LI H.M., QIAN X., HU W., WANG Y.L., GAO H.L. Chemical speciation and human health risk of trace metals in urban street dusts from a metropolitan city, Nanjing, SE China. Science of the Total Environment 456-457, 212, 2013.

38. KANWAL R., FIZA F., IQRA W., MUHAMMAD SAJD H.A. Prevalence of exposure of heavy metals and their impact on health consequences[J]. Journal of Cellular Biochemistry 117, 159, 2018.

39. RAMDANI S., AMAR A., BELHSAIEN K. Assessment of Heavy Metal Pollution and Ecological Risk of Roadside Soils in Tlemcen (Algeria) Using Flame-Atomic Absorption Spectrometry. Analytical Letters 51, 2468, 2018.

40. CHAND N., TYAG I.S., PRASAD R., SIROHI A.S., YADAV B.P.S. Heavy Metal and Trace Mineral Profile in Blood and Hair of Cattle Reared Around Industrial
Effluent Contaminated Area. Journal of Applied Animal Research 7, 685, 2017.

41. SONG S. Environmental Investigation and Category Analysis of Solid Wastes in Heavy Metal Pollution Industrial Sites- Taking an industrial contaminated site in a city of Jiangxi Province as an example. Materials and Science and Engineering 631, 22007, 2019.

42. ETIM E.U., ONIANWA P.C. Heavy Metal Pollution of Topsoil in the Vicinity of an Industrial Estate Co-Located with a Housing Estate in Southwestern Nigeria. Journal of Environmental Protection Ecology 4, 91, 2013.

43. CHENG H.X., LEI H., MA P.T., YI S. Ecological Risk and Restoration Measures Relating to Heavy Metal Pollution in Industrial and Mining Wastelands. Environmental Science Pollution Research 6, 3985, 2019.

44. LIU Y., YANG Y.J., LI C.X., NI X.L., MA W.C., WEI H. Assessing Soil Metal Levels in an Industrial Environment of Northwestern China and the Phytoremediation Potential of Its Native Plants. Sustainability 10, 1, 2018.

45. Ministry of Ecology and Environment of the people's Republic of China. Risk Control Standard for Soil Contamination Risk Screening Values for Soil Contamination of Development Land (GB 36600-2018), 2018.

46. LI W.L., XU B.B., SONG Q.J., LIU X.M., XU J.M., PHILIP C. The identification of 'hotspots' of heavy metal pollution in soil-rice systems at a regional scale in Eastern China. Science of the Total Environment 472, 407, 2014.

47. KANDULU J.M., CONNOR J.D. Improving the effectiveness of aid: an evaluation of prospective Mekong irrigation investments. International Journal of Water Research Development 33, 270, 2017.

48. GAO J., WANG L.C. Ecological and human health risk assessments in the context of soil heavy metal pollution in a typical industrial area of Shanghai, China. Environemental Science and Pollution and Research 25, $27090,2018$.

49. HUANG Y., CHEN Q.Q., DENG M.H. Heavy metal pollution and health risk assessment of agricultural soils in a typical peri-urban area in southeast China. Journal of Environmental Management 20, 159, 2018.

50. IMPERATO M., ADAMO P., NAIMO D. Spatial distribution of heavy metals in urban soils of Naples city (Italy). Environmental Pollution 124, 247, 2003.

51. GUO W., ZHANG H.Y., CUI S.B., XU Q.G., TANG Z.W., GAO F. Assessment of the distribution and risks of organochlorine pesticides in core sediments from areas of different human activity on Lake Baiyangdian, China. Stochastic Environmental Research Risk Assessment 28, $1035,2014$.

52. KHALILOVA H., MAMMADOV V. Assessing the Anthropogenic Impact on Heavy Metal Pollution of Soils and Sediments in Urban Areas of Azerbaijan's Oil Industrial Region (China). Polish Journal of Environmental Studies 25 (1), 50, 2016.

53. ZAKIR H.M., SUMI S.A., SHARMIN S., MOHIUDDIN K.M., KAYSAR S. Heavy metal contamination in surface soils of some industrial areas of Gazipur, Bangladesh. The Journal of Chemical Physics 5, 2191, 2015.

54. MA W.C., TAI L.Y., QIAO Z. Contamination source apportionment and health risk assessment of heavy metals in soil around municipal solid waste incinerator: a case study in North China. Science of the Total Environment 631-632, 348, 2018.

55. WEI B.G., YANG L.S. A review of heavy metal contaminations in urban soils, urban road dusts and agricultural soils from China. Microchemical Journal 94, 99, 2010. 
56. WANG F.F., GUAN Q.Y., TIAN J., LIN J.K., YANG Y.Y., YANG L.Q., PAN N.H. Contamination characteristics, source apportionment, and health risk assessment of heavy metals in agricultural soil in the Hexi Corridor. Catena 191, 104573, 2020.

57. ISLAM M.S., AHMED M.K., HABIBULLAH-ALMAMUN M. Apportionment of heavy metals in soil and vegetables and associated health risks assessment. Stochastic Environmental Research and Risk Assessment 30, 365, 2016.

58. NANOS N., GRIGORATOS T., RODRIGUEZ MARTIN J.A., SAMARA C. Scale dependent correlations between soil heavy metals and As around four coal-fired power plants of northern Greece. Stochastic Environmental Research and Risk Assessment 29, 1531, 2015.

59. NARTEY V.K., EDOR K.A., DOAMEKPOR L.K., BOBOBEE LH. Spatial Distribution of Heavy Metals in Surface Sediments of the Sakumo Lagoon, Ghana. Journal of Environmental Science \& Engineering 4, 17, 2011.

60. JIAO X.D., TENG Y.G., ZHAN Y.H., WU J., LIN X.Y. Soil Heavy Metal Pollution and Risk Assessment in Shenyang Industrial District, Northeast China. PloS One 10 (5), 127736, 2015.

61. PERAlTA E., GUSTAVO P., OJEDA G., JOSEP M.A., MARIA-JESUS S.M. Heavy metal availability assessment using portable X-ray fluorescence and single extraction procedures on former vineyard polluted soils. Science of the Total Environment 726, 138670, 2020.

62. KLAKE R.K. Correlation between Heavy Metals in Fish and Sediment in Sakumo and Kpeshie Lagoons, Ghana. Journal of Environmental Protection 3, 1070, 2012.
63. BAYRAKH B., DENGIZ O. Determination of heavy metal risk and their enrichment factor in intensive cultivated soils of Tokat Province. Eurasian Soil Science 8, 249, 2019.

64. KARA G.T., KARA M., BAYRAM A., GUNDUZ O. ABDURRAHMAN Assessment of seasonal and spatial variations of physicochemical parameters and trace elements along a heavily polluted effluent-dominated stream. Environmental Monitoring and Assessment 189, 585.1-585.6, 2017.

65. RAJBALA S. Impact of steel industry waste on physicochemical property of soil. International Journal of Environmental Science 2, 1144, 2012.

66. OMAR N.A., PRAVEENA S.M., ARIS A.Z., HASHIM Z. Health Risk Assessment using in vitro digestion model in assessing bioavailability of heavy metal in rice: A preliminary study. Food chemistry 188, 46, 2015.

67. ZHANG R., CHEN T., ZHANG Y. Health risk assessment of heavy metals in agricultural soils and identification of main influencing factors in a typical industrial park in northwest China. Chemosphere 252, 126591, 2020.

68. LI L., WANG S.J., SHEN X.Q., JIANG M. Ecological risk assessment of heavy metal pollution in the water of China's coastal shellfish culture areas. Environmental Science and Pollution Research 27, 18392-18402, 2020.

69. TANG J., HE J.G., TANG H.J., et al. Heavy metal removal effectiveness, flow direction and speciation variations in the sludge during the biosurfactant-enhanced electrokinetic remediation. Separation and Purification Technology 246, 116918, 2020

\section{Supplementary Materials}

\section{Abbreviation for Industry}

Abbreviation for industry is listed in Table S1.

The agriculture land is surrounded with the industrial area and the assessment standard of agriculture land is used, so the sample points were attained in the area of key monitor industries surrounding. The sample point of different industries is basically similar. In site A, AI collected four samples in southwest, northwest, southeast and northeast. GM(a) collected four samples in east, south, west, north. CI collected four samples in southeast, east, south and north. TI(a) collected four samples in northeast, northwest, south and north. SG collected four samples in southeast, southwest, northeast and south. RL collected four samples in east, southeast, southwest and west. WIP collected five samples in east, west, northeast and southwest. Nevertheless, WDI is larger than other industries, so the six samples were collected in east, south, west, north, southwest and northeast. In site B, FCP collected four samples in southeast, southwest, northwest and northeast. LI collected four samples in south, east, southeast and northwest. GM(b) collected five samples in east, west, south, north and northwest. TI(b) collected five samples in south, east, west, southeast and southwest. The number of sample points in site A is 34 and sample points in site B is 18 . These points are located on the area of agriculture lands in order to let all points available on the condition of agriculture land assessment.

\section{Soil Sampling and Analysis}

The quality control requirements related to soil environmental monitoring technical specifications are strictly implemented for soil sample collection, preparation and sample pre-treatment. For $\mathrm{Hg}$ and As, " $1+1 \mathrm{HNO}_{3}-\mathrm{HCl}$ " (1:5 in volume) is used for digestion, and then atomic fluorescence method is used for analysis; for $\mathrm{Cd}, \mathrm{Pb}, \mathrm{Cr}, \mathrm{Cu}, \mathrm{Zn}$ and $\mathrm{Ni}$, four acids for $\mathrm{HNO}_{3}$ - $\mathrm{HCl}-\mathrm{HF}-\mathrm{HClO}_{4}(5: 5: 5: 3$ in volume) are used for digestion, and then graphite furnace atomic absorption spectrophotometry is used for analysis. The concentrations of heavy metals $(\mathrm{Cd}, \mathrm{Cr}, \mathrm{Cu}, \mathrm{Ni}, \mathrm{Pb}$, and $\mathrm{Zn}$ ) were analyzed by inductively coupled plasma mass spectrometry(ICP - MS, PerkinElmer NexION 350X, USA), and $\mathrm{As}$ and $\mathrm{Hg}$ were measured using atomic fluorescence spectrometry (PF7-2, Beijing Purkinje General Instrument Ltd., Beijing, China). Quality assurance and quality control (QA/QC) were conducted by reagent blanks, duplicates, and standard reference 
Table S1. Abbreviation for different industries.

\begin{tabular}{|c|c|c|c|}
\hline Order & Region & Industry & Abbreviation \\
\hline 1 & \multirow{8}{*}{ Site A } & Agate Industry & AI \\
\hline 2 & & Gold Mining(a) & GM(a) \\
\hline 3 & & Copper Industry & $\mathrm{CI}$ \\
\hline 4 & & Titanium Industry & $\mathrm{TI}(\mathrm{a})$ \\
\hline 5 & & Switch Gear & SG \\
\hline 6 & & Waster Disposal Industry & WDI \\
\hline 7 & & Refuse Landfill & RL \\
\hline 8 & & Waste Industrial Park & WIP \\
\hline 9 & \multirow{4}{*}{ Site B } & Fluorine Chemical Park & $\mathrm{FCP}$ \\
\hline 10 & & Leather Industry & LI \\
\hline 11 & & Golden Mining & $\mathrm{GM}(\mathrm{b})$ \\
\hline 12 & & Titanium Industry & TI(b) \\
\hline
\end{tabular}

material (GBW07401, Center of National Standard Reference Material of China). The recovery rates ranged from $92.86 \%$ to $105.21 \%$. Three duplicates were used for all analyses, and relative standard deviations of duplicate samples were less than $5.0 \%$.

In order to ensure the accuracy of quality control and analysis, the pre-treatment and analysis of this study adopt The national environmental monitoring plan in 2014. The soil environmental quality evaluation standard follows The risk screening value and environment in the soil pollution risk control standard for agricultural land (GB15618-2018) and The technical regulations for the evaluation of the state of soil pollution (HF [2008] No. 39). In this study, the background value comes from [1]. The risk screening risk is ensured connecting with $\mathrm{pH}$ value in local areas. The $\mathrm{pH}$ value in study soils is between 6.5-7.5, so the background value and risk screening value are listed in Table S2. The variety of soils around industrial areas is agricultural land, so the evaluation standard of risk screening value uses agricultural land evaluation criteria.

\section{Potential Ecological and Health Risk Assessment}

\section{Potential Ecological Assessment}

The geoaccumulation index $\left(\mathrm{I}_{\text {geo }}\right)$ was proposed by the German scientist Muller in 1969 and developed in Europe to study the quantitative indicators of heavy metal pollution in sediment and other materials. Calculation method in soil of $\mathrm{I}_{\mathrm{geo}}$ in this study is as follows:

$$
I_{\mathrm{geo}}=\log _{2}\left(C / K C_{b}\right)
$$

...where:

$\mathrm{C}$ - the concentration of heavy metals in soil

$\mathrm{C}_{\mathrm{b}}$ - the Background Value of heavy metals in soil $\mathrm{K}$ - the background matrix is 1.5 in this study. $\mathrm{K}$ was introduced to mitigate the ancillary effects of changes in soil lithology.

RI was estimated as follows:

Table S2. The background value and risk screening value in this study.

\begin{tabular}{|c|c|c|c|c|c|c|c|c|}
\hline Heavy metal & $\mathrm{Cd}$ & $\mathrm{Pb}$ & $\mathrm{Cr}$ & $\mathrm{Cu}$ & $\mathrm{Ni}$ & $\mathrm{Zn}$ & $\mathrm{As}$ & $\mathrm{Hg}$ \\
\hline Background value & 0.11 & 20.30 & 57.90 & 19.80 & 23.80 & 59.80 & 8.80 & 0.04 \\
\hline Risk screening value & 0.3 & 120 & 200 & 100 & 100 & 250 & 30 & 2.4 \\
\hline
\end{tabular}

Table S3. The Tr value of different heavy metal.

\begin{tabular}{|c|c|c|c|c|c|c|c|c|}
\hline Heavy metal & $\mathrm{Cd}$ & $\mathrm{Pb}$ & $\mathrm{Cr}$ & $\mathrm{Cu}$ & $\mathrm{Ni}$ & $\mathrm{Zn}$ & $\mathrm{As}$ & $\mathrm{Hg}$ \\
\hline $\mathrm{T}_{\mathrm{r}}$ & 5 & 5 & 2 & 5 & 5 & 5 & 10 & 40 \\
\hline
\end{tabular}


Table S4. The pollution assessment of Igeo, Er and RI.

\begin{tabular}{|c|c|c|}
\hline Index & Category & Description \\
\hline \multirow{5}{*}{$\mathrm{I}_{\text {geo }}$} & $\mathrm{I}_{\text {geo }} \leq 0$ & Practically uncontaminated \\
\cline { 2 - 3 } & $0<\mathrm{I}_{\text {geo }} \leq 1$ & Uncontaminated moderately contaminated \\
\cline { 2 - 3 } & $1<\mathrm{I}_{\text {geo }} \leq 2$ & Moderately contaminated \\
\cline { 2 - 3 } & $2<\mathrm{I}_{\text {geo }} \leq 3$ & Moderately to heavily contaminated \\
\cline { 2 - 3 } & $3<\mathrm{I}_{\text {geo }} \leq 4$ & Heavily contaminated \\
\cline { 2 - 3 } & $4<\mathrm{I}_{\text {geo }} \leq 5$ & Heavily extremely contaminated \\
\hline \multirow{5}{*}{$\mathrm{RI}$} & $5<\mathrm{I}_{\text {geo }}$ & Extremely contaminated \\
\cline { 2 - 3 } & $\mathrm{RI} \leq 150 ; \mathrm{E}_{\mathrm{r}}^{\mathrm{i}} \leq 40$ & Low risk \\
\cline { 2 - 3 } & $150<\mathrm{RI} \leq 300 ; 40<\mathrm{E}_{\mathrm{r}}^{\mathrm{i}} \leq 80$ & Moderate risk \\
\cline { 2 - 3 } & $300<\mathrm{RI} \leq 600 ; 80<\mathrm{E}_{\mathrm{r}}^{\mathrm{i}} \leq 160$ & Considerable risk \\
\cline { 2 - 3 } & $600<\mathrm{RI} ; 160<\mathrm{E}_{\mathrm{r}}^{\mathrm{i}} \leq 320$ & High risk \\
\cline { 2 - 3 } & $320<\mathrm{E}_{\mathrm{r}}^{\mathrm{r}}$ & Extreme risk \\
\hline
\end{tabular}

$$
\begin{aligned}
& R I=\sum E_{\mathrm{r}} \\
& E_{\mathrm{r}}=T_{r} \times C_{f} \\
& C_{\mathrm{f}}=C_{0} / C_{\mathrm{b}}
\end{aligned}
$$

...where:

$E_{\mathrm{r}}$ - the potential ecological risk factor for a single element

$T_{\mathrm{r}}$ - the toxicity coefficients for heavy metal, the $\mathrm{Tr}$ values are shown as Table S3.

$C_{\mathrm{f}}$ - the pollution factor

$C_{0}$ - the mean concentration of heavy metal

$C_{\mathrm{b}}$ - the background reference value of heavy metal

The $I_{\text {geo }}$ assessment of Pollution Level and the pollution assessment of RI is shown as Table S4.

\section{Potential Health Assessment}

To describe the probability of non-carcinogenic and CRs of heavy metals to humans, health risk was assessed. In this study, adults and children were selected as the exposed people, where ingestion, dermal contact, and inhalation were selected as exposure pathways. The average daily intake $(A D I)$ of each heavy metal was estimated by the following equations :

$$
\begin{gathered}
A D I_{\text {ing }}=C \times \frac{\operatorname{Ing} R \times E F \times E D}{B W \times A T} \times 10^{-6} \\
A D I_{\text {derm }}=C \times \frac{S A \times A F \times A B S \times E F \times E D}{B W \times A T} \times 10^{-6}
\end{gathered}
$$

$$
A D I_{\mathrm{derm}}=C \times \frac{S A \times A F \times A B S \times E F \times E D}{B W \times A T} \times 10^{-6}
$$

...where:

$A D I_{i n g}, A D I_{\text {derm }}$, and $A D I_{i n h}$ (mg/kg/day) - the $A D I \mathrm{~s}$ via ingestion, dermal contact, and inhalation, respectively $C$ - the concentration of heavy metal in soil $(\mathrm{mg} / \mathrm{kg})$ IngR - the ingestion rate of soil (mg/day)

$\mathrm{EF}$ - the exposure frequency (day/year)

ED - exposure duration (year)

BW - body weight $(\mathrm{kg})$

AT - average time (day)

InhR - the inhalation rate of soil ( $\left.\mathrm{m}^{3} / \mathrm{day}\right)$

$\mathrm{PEF}$ - the particle emission factor $\left(\mathrm{m}^{3} / \mathrm{kg}\right)$

SA - the surface area of the skin in contact with soil $\left(\mathrm{cm}^{2}\right)$

AF - the relative skin adherence factor $\left(\mathrm{mg} / \mathrm{cm}^{2}\right)$

ABS - the dermal absorption fraction of heavy metal (unitless).

The values of these parameters were referenced from a previous study [2] and as shown in Table S5.

The non-CR (HQ) was assessed by the following equation [3]:

$$
\begin{gathered}
H Q_{i}=A D I_{i} / R f D_{i} \\
H I_{\mathrm{i}}=\sum H Q_{i}
\end{gathered}
$$

...where:

$R f D$ - corresponding reference dose $(\mathrm{mg} / \mathrm{kg} / \mathrm{day})$

$i$ - exposure pathways.

HI - the non-CR caused by all exposure pathways.

If $\mathrm{HI}$ is higher than 1, then it indicates that the heavy metal poses non-CRs to humans. On the contrary, if HI 
Table S5. Different values of parameters in exposure assessment.

\begin{tabular}{|c|c|c|c|c|}
\hline & \multirow{2}{*}{ Parameter } & \multirow{2}{*}{ Unit } & \multicolumn{2}{|c|}{ Group classification } \\
\hline & & & Adult & Children \\
\hline & IngR & $m g$ day $^{-1}$ & 100 & 200 \\
\hline & $\mathrm{EF}$ & day year ${ }^{-1}$ & 350 & 350 \\
\hline & ED & year & 24 & 6 \\
\hline & InhR & $\mathrm{m}^{3}$ day $^{-1}$ & 20 & 7.5 \\
\hline & PEF & $\mathrm{m}^{3}$ day $^{-1}$ & $1.36 \times 10^{9}$ & $1.36 \times 10^{9}$ \\
\hline & SA & $\mathrm{cm}^{2}$ & 5700 & 2800 \\
\hline & $\mathrm{AF}$ & $\mathrm{mg} \mathrm{cm}{ }^{-2}$ & 0.07 & 0.2 \\
\hline \multirow{2}{*}{ ABS } & Non-carcinogenic & - & 0.001 & 0.001 \\
\hline & Carcinogenic & - & 0.01 & 0.01 \\
\hline \multicolumn{2}{|r|}{ BW } & $\mathrm{kg}$ & 70 & 15 \\
\hline \multirow{2}{*}{ AT } & Non-carcinogenic & day & 8760 & 2190 \\
\hline & Carcinogenic & day & 25550 & 25550 \\
\hline
\end{tabular}

is lower than 1, then the non-CRs are small-beer. The values of RfD were referenced from a previous study [4], and as shown in Table S6.

CR was calculated as follows [5]:

$$
\begin{gathered}
C R_{\mathrm{i}}=A D I_{\mathrm{i}} \times S F \\
C R=\sum C R_{\mathrm{i}}
\end{gathered}
$$

...where

$\mathrm{SF}$ - the carcinogenic slope factor ( $\mathrm{mg} / \mathrm{kg} /$ day)

$i$ - exposure pathways.

If $\mathrm{CR}$ is lower than $1 \times 10^{-6}$, then it indicates negligible health hazards. If $1 \times 10^{-6} \leq \mathrm{CR} \leq 1 \times 10^{-4}$, then it indicates that the $\mathrm{CR}$ is acceptable or tolerable. If CR is higher than $1 \times 10^{-4}$, then it indicates an unacceptable CR. Table S6. displays the unit and value of SF.

\section{The Results of Health Risk Assessment}

The Result of Non-Cancer Risk

The result is listed in Table S7.

The Result of Cancer Risk

The result is listed in Table S8.

Table S6. Values of RfD and SF of different heavy metal in three exposure pathway.

\begin{tabular}{|c|c|c|c|c|c|c|}
\hline \multirow{2}{*}{ Heavy metal } & \multicolumn{3}{|c|}{$\mathrm{RfD}$} & \multicolumn{3}{c|}{$\mathrm{SF}$} \\
\cline { 2 - 6 } & $\mathrm{RfD}_{\text {ing }}$ & $\mathrm{RfD}_{\text {derm }}$ & $\mathrm{RfD}_{\text {inh }}$ & $\mathrm{SF}_{\text {ing }}$ & $\mathrm{SF}_{\text {derm }}$ & $\mathrm{SF}_{\text {inh }}$ \\
\hline $\mathrm{Cd}$ & $1.00 \times 10^{-3}$ & $2.50 \times 10^{-5}$ & $5.71 \times 10^{-5}$ & - & - & 6.3 \\
\hline $\mathrm{Pb}$ & $1.40 \times 10^{-4}$ & $1.40 \times 10^{-4}$ & - & - & - & - \\
\hline $\mathrm{Cr}$ & 1.50 & $1.95 \times 10^{-2}$ & $2.86 \times 10^{-5}$ & $5.01 \times 10^{-1}$ & 20 & 42 \\
\hline $\mathrm{Cu}$ & $4.00 \times 10^{-2}$ & $4.00 \times 10^{-2}$ & - & - & - & - \\
\hline $\mathrm{Ni}$ & $2.00 \times 10^{-2}$ & $8.00 \times 10^{-4}$ & $2.06 \times 10^{-2}$ & 1.7 & 42.5 & $9.01 \times 10^{-1}$ \\
\hline $\mathrm{Zn}$ & $3.00 \times 10^{-1}$ & $3.00 \times 10^{-1}$ & $3.00 \times 10^{-1}$ & - & - & - \\
\hline $\mathrm{As}$ & $3.00 \times 10^{-4}$ & $3.00 \times 10^{-4}$ & $3.00 \times 10^{-4}$ & 1.50 & 3.66 & 15.1 \\
\hline $\mathrm{Hg}$ & $1.60 \times 10^{-4}$ & $1.60 \times 10^{-4}$ & $8.57 \times 10^{-5}$ & - & - & - \\
\hline
\end{tabular}




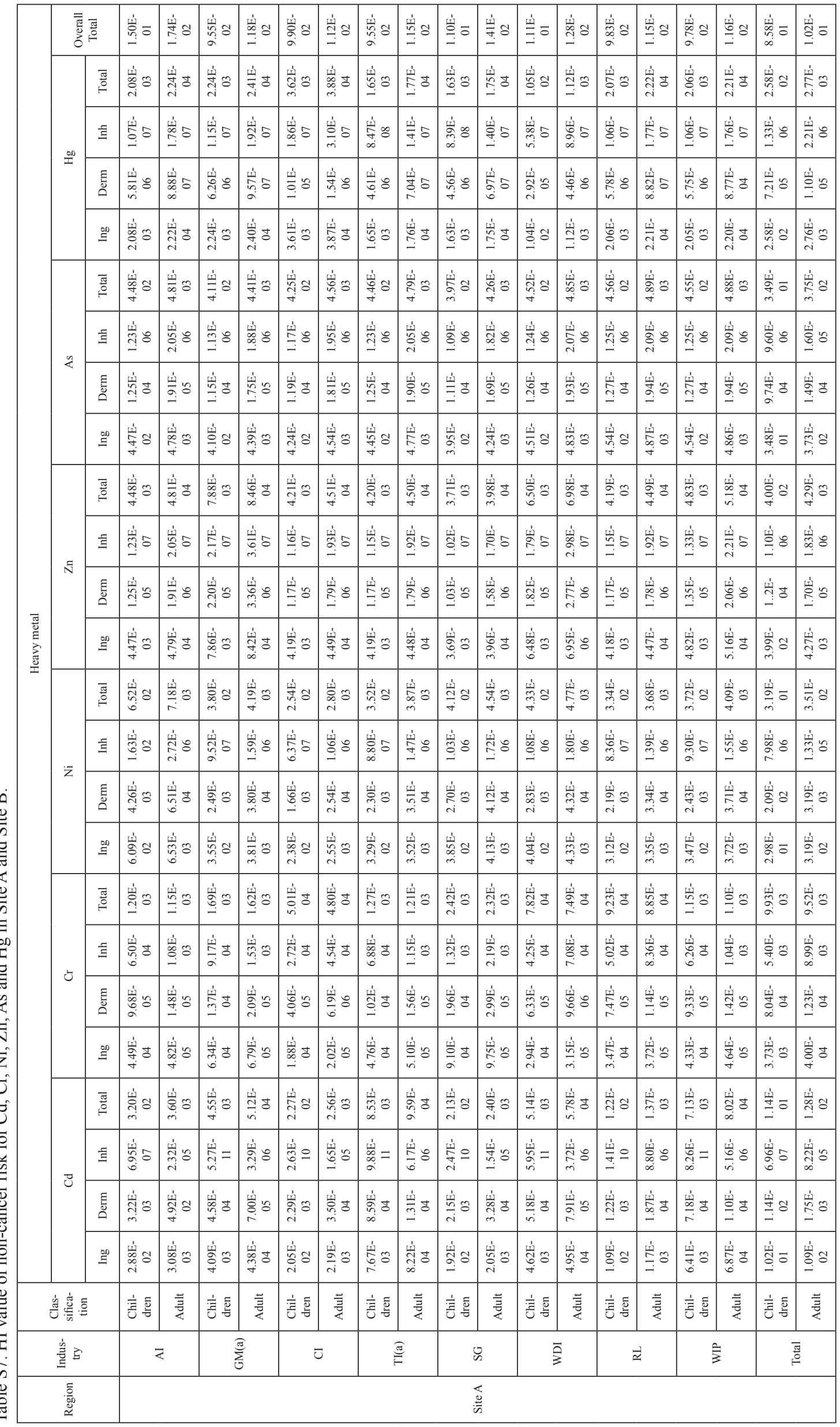




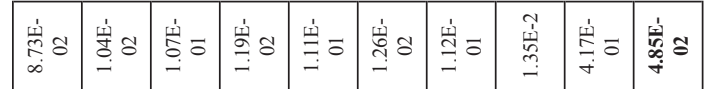

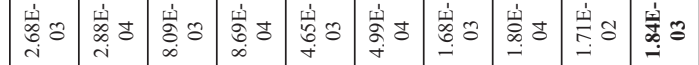

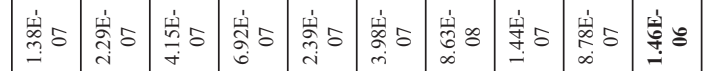

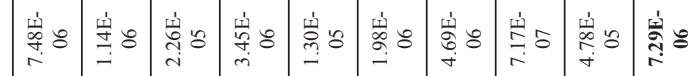

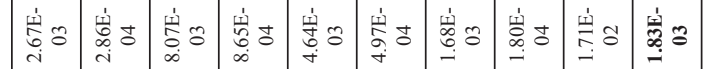

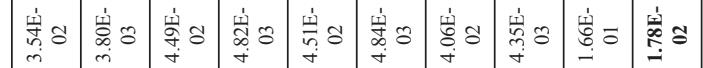

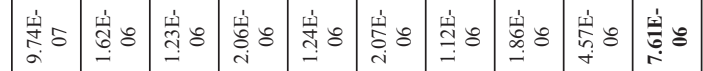

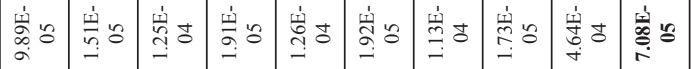

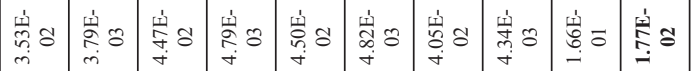

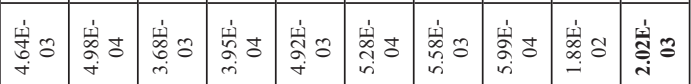

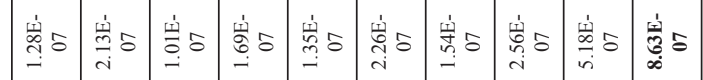

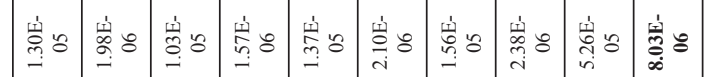

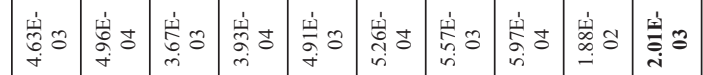

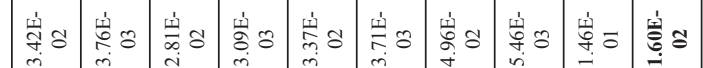

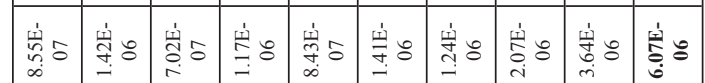

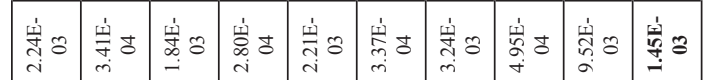

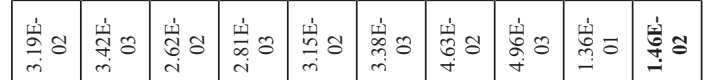

离实

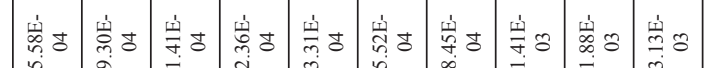

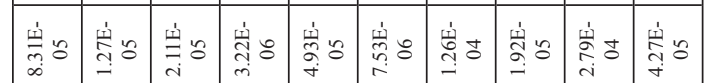

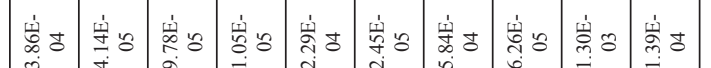

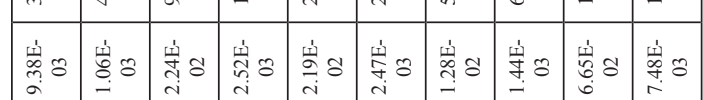

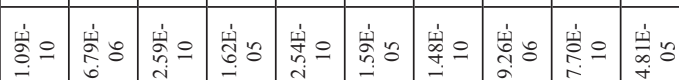

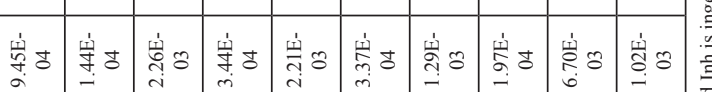

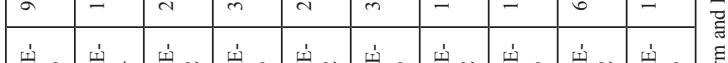

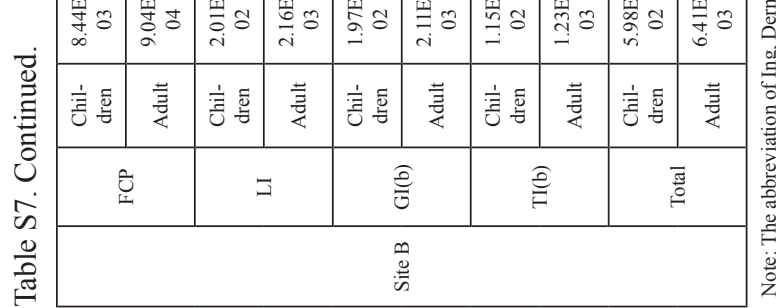

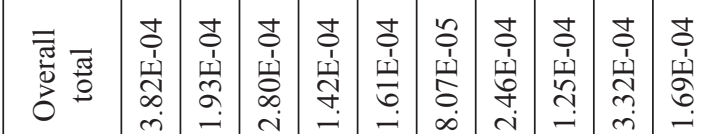

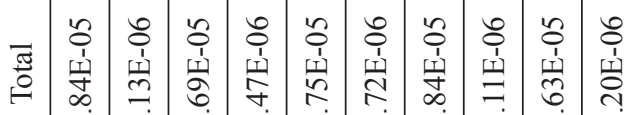

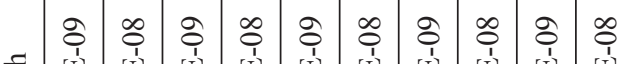

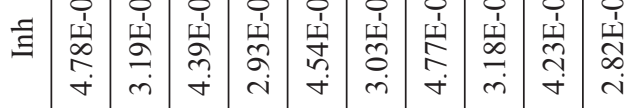

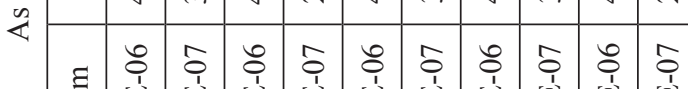

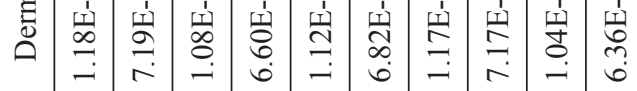

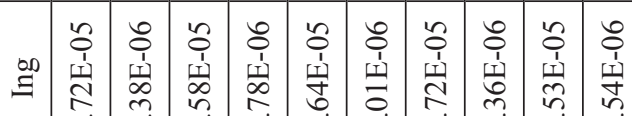

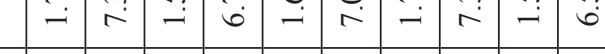

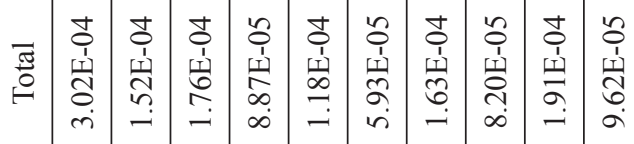

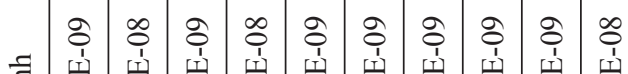

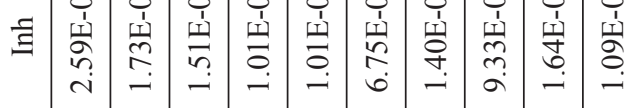

z

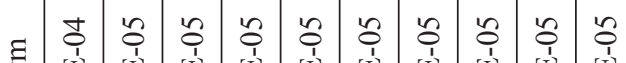

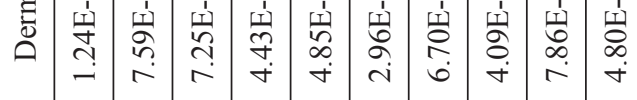

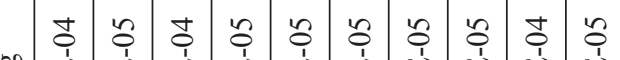

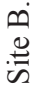

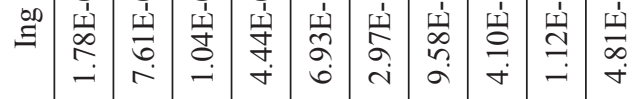

F

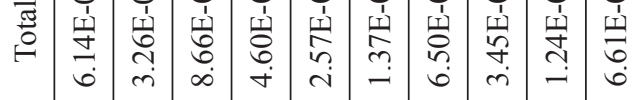

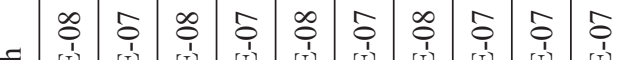

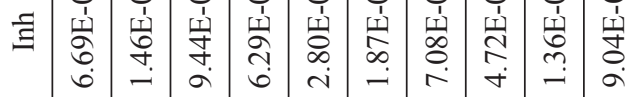

Ü

to

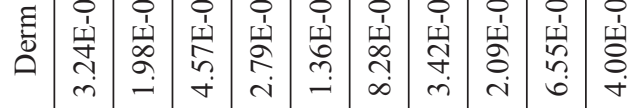

nô

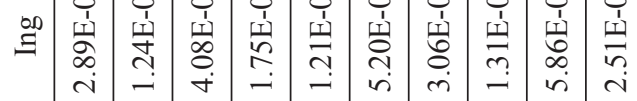

$\bar{z}$

U⿺辶,

苞

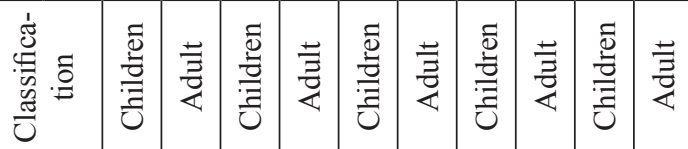

\begin{tabular}{|c|c|c|c|c|c|}
\hline 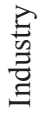 & 飞 & $\sum_{0}^{\overparen{J}}$ & $\widetilde{U}$ & $\underset{F}{\stackrel{\Xi}{E}}$ & U \\
\hline $\begin{array}{l}\stackrel{\Xi}{0} \\
\stackrel{0}{00} \\
\stackrel{0}{\simeq}\end{array}$ & & & 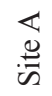 & & \\
\hline
\end{tabular}




\begin{tabular}{|c|c|c|c|c|c|c|c|c|c|c|c|c|c|c|c|c|c|}
\hline $\begin{array}{l}0 \\
\text { In } \\
\text { hे } \\
\text { in }\end{array}$ & 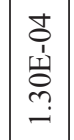 & 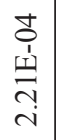 & 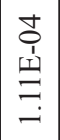 & 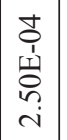 & 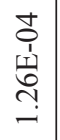 & 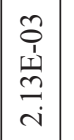 & 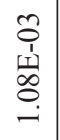 & 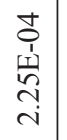 & 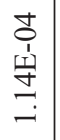 & 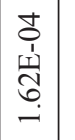 & $\begin{array}{l}0 \\
0 \\
1 \\
1 \\
0 \\
\infty \\
\infty\end{array}$ & $\begin{array}{l}\mathbf{d} \\
\stackrel{1}{1} \\
\stackrel{1}{0} \\
\stackrel{i}{i}\end{array}$ & 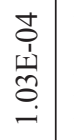 & 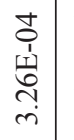 & 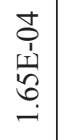 & 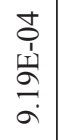 & 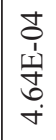 \\
\hline 8 & \begin{tabular}{c}
$\stackrel{0}{0}$ \\
$\stackrel{1}{1}$ \\
\multicolumn{1}{c}{} \\
\\
$\infty$
\end{tabular} & $\begin{array}{c}n \\
o \\
1 \\
\\
\stackrel{1}{\infty} \\
- \\
-\end{array}$ & \begin{tabular}{|c|} 
\\
0 \\
1 \\
1 \\
$\infty$ \\
$\sim$ \\
\\
$\infty$ \\
\end{tabular} & $\begin{array}{c}n \\
0 \\
0 \\
\omega \\
\infty \\
\infty \\
\infty \\
-\end{array}$ & $\begin{array}{c}\stackrel{0}{0} \\
1 \\
\text { ț } \\
\sim \\
\infty \\
\infty\end{array}$ & 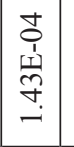 & 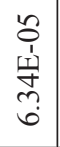 & 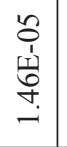 & 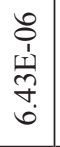 & $\begin{array}{c}\qquad \\
o \\
1 \\
1 \\
⿱ 亠 䒑 \\
\infty \\
- \\
-\end{array}$ & 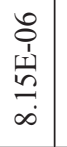 & $\begin{array}{l}\stackrel{n}{0} \\
\text { ț } \\
\stackrel{1}{0} \\
\stackrel{\infty}{-} \\
-\end{array}$ & $\begin{array}{l}8 \\
\vdots \\
1 \\
\stackrel{1}{0} \\
\infty \\
\infty\end{array}$ & 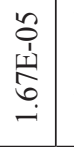 & 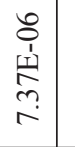 & 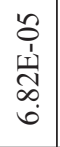 & 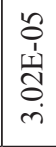 \\
\hline 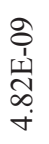 & 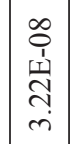 & 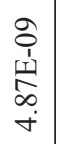 & \begin{tabular}{l}
$\infty$ \\
0 \\
1 \\
\multirow{1}{+}{} \\
$\underset{n}{n}$
\end{tabular} & 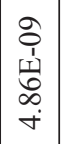 & 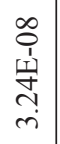 & \begin{tabular}{|c|c}
$\infty$ \\
0 \\
1 \\
\\
$i$ \\
$\dot{n}$
\end{tabular} & 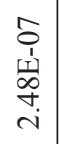 & \begin{tabular}{l}
$\stackrel{a}{ }$ \\
$\hat{1}$ \\
\multicolumn{1}{c}{} \\
$\infty$ \\
$\dot{r}$
\end{tabular} & $\begin{array}{c}\infty \\
0 \\
1 \\
\stackrel{1}{N} \\
\\
i\end{array}$ & \begin{tabular}{l}
$\stackrel{a}{+}$ \\
1 \\
\multirow{1}{2}{} \\
$\dot{+}$
\end{tabular} & $\begin{array}{l}\infty \\
0 \\
\dot{1} \\
\stackrel{1}{2} \\
\dot{m}\end{array}$ & 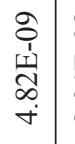 & 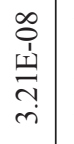 & 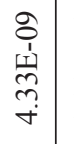 & 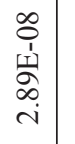 & 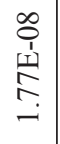 & 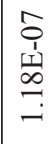 \\
\hline $\begin{array}{l}\text { \& } \\
\text { İ } \\
\text { İ }\end{array}$ & $\begin{array}{l}\hat{o} \\
\stackrel{1}{1} \\
\\
\\
\end{array}$ & 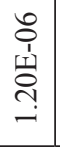 & 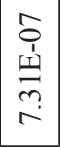 & 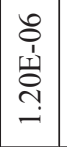 & 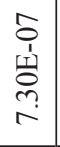 & 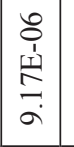 & 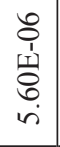 & 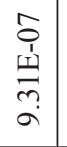 & 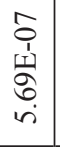 & $\begin{array}{c}0 \\
0 \\
1 \\
1 \\
\infty \\
-1 \\
-1 \\
-1\end{array}$ & 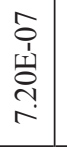 & 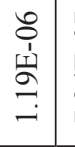 & $\begin{array}{c}\hat{o} \\
\stackrel{1}{1} \\
\stackrel{y}{+} \\
\stackrel{n}{r}\end{array}$ & 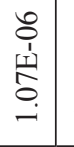 & $\begin{array}{l}\hat{0} \\
1 \\
\underline{1} \\
\\
0\end{array}$ & 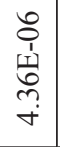 & $\begin{array}{l}0 \\
0 \\
1 \\
1 \\
0 \\
0 \\
i \\
i\end{array}$ \\
\hline 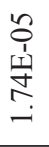 & 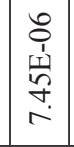 & 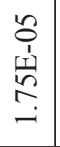 & 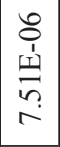 & 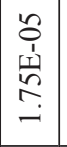 & 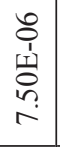 & 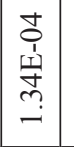 & $\begin{array}{c}n \\
o \\
1 \\
1 \\
\\
i \\
i n\end{array}$ & $\begin{array}{c}n \\
o \\
1 \\
1 \\
0 \\
\\
-\end{array}$ & 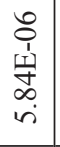 & 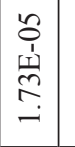 & 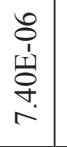 & 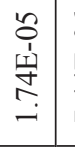 & 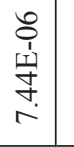 & $\begin{array}{l}\stackrel{n}{0} \\
1 \\
\text { ț } \\
\stackrel{n}{?}\end{array}$ & 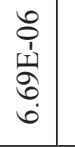 & 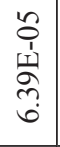 & \begin{tabular}{l}
$n$ \\
$o$ \\
$o$ \\
I \\
\multirow{1}{t}{} \\
i
\end{tabular} \\
\hline 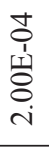 & 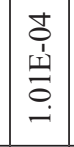 & 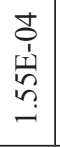 & 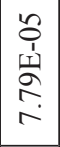 & 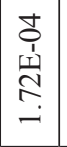 & $\begin{array}{l}r \\
0 \\
1 \\
1 \\
0 \\
0 \\
\infty \\
\infty\end{array}$ & 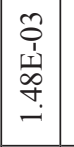 & $\begin{array}{l}n \\
0 \\
1 \\
\\
0 \\
\infty \\
\infty\end{array}$ & $\begin{array}{c}t \\
0 \\
1 \\
1 \\
\infty \\
\\
-\end{array}$ & $\begin{array}{l}n \\
o \\
1 \\
\\
\vdots \\
r\end{array}$ & 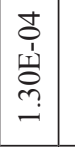 & \begin{tabular}{l}
$n$ \\
0 \\
1 \\
1 \\
\multirow{1}{*}{} \\
6
\end{tabular} & 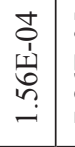 & 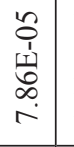 & 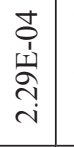 & 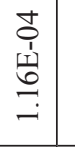 & 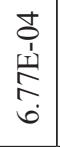 & 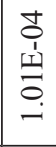 \\
\hline $\begin{array}{l}\stackrel{2}{o} \\
\text { 1 } \\
\stackrel{1}{N} \\
\text { i }\end{array}$ & $\begin{array}{c}\infty \\
0 \\
1 \\
1 \\
\\
= \\
- \\
\end{array}$ & $\begin{array}{c}\stackrel{2}{o} \\
\stackrel{1}{1} \\
\stackrel{m}{2} \\
\stackrel{-}{-}\end{array}$ & \begin{tabular}{|c|}
0 \\
0 \\
1 \\
1 \\
$\infty$ \\
$\infty$ \\
$\infty$ \\
$\infty$ \\
\end{tabular} & 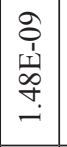 & 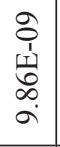 & \begin{tabular}{|c|}
$\infty$ \\
0 \\
0 \\
1 \\
\\
\\
-1 \\
\end{tabular} & $\begin{array}{c}\infty \\
0 \\
\vdots \\
1 \\
1 \\
+ \\
\infty \\
\infty \\
\end{array}$ & 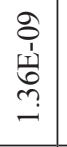 & 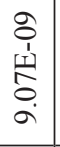 & 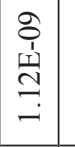 & 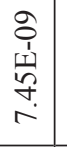 & 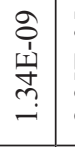 & $\begin{array}{l}n \\
o \\
1 \\
\\
\infty \\
\infty\end{array}$ & $\begin{array}{c}\text { ò } \\
\stackrel{1}{1} \\
\text { ஸे } \\
\stackrel{-}{-}\end{array}$ & 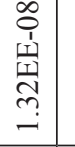 & 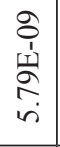 & \begin{tabular}{|l}
$\infty$ \\
0 \\
1 \\
1 \\
0 \\
$\infty$ \\
$\infty$ \\
\end{tabular} \\
\hline 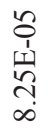 & $\mid$\begin{tabular}{c}
$n$ \\
$o$ \\
1 \\
1 \\
\multirow{1}{0}{} \\
$\dot{r}$ \\
$r$
\end{tabular} & $\mid \begin{array}{c}n \\
o \\
\hat{1} \\
\\
\\
b\end{array}$ & 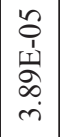 & $\mid \begin{array}{l}n \\
0 \\
1 \\
1 \\
0 \\
0 \\
r \\
r\end{array}$ & 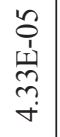 & $\begin{array}{l}0 \\
0 \\
1 \\
1 \\
0 \\
0 \\
0 \\
0\end{array}$ & 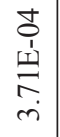 & \begin{tabular}{l} 
on \\
1 \\
\multicolumn{1}{|c}{} \\
\\
$b$
\end{tabular} & 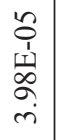 & $\mid$ & 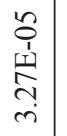 & 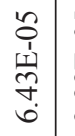 & $\begin{array}{l}\stackrel{r}{0} \\
\dot{1} \\
\tilde{n} \\
\dot{m}\end{array}$ & 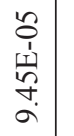 & 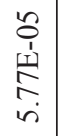 & 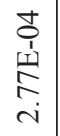 & 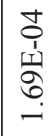 \\
\hline 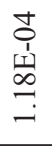 & $\begin{array}{c}n \\
o \\
1 \\
1 \\
o \\
i \\
i n\end{array}$ & 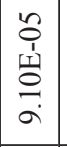 & 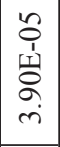 & 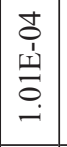 & 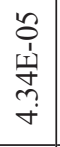 & \begin{tabular}{|c|} 
\\
0 \\
1 \\
tad \\
6 \\
$\infty$ \\
$\infty$ \\
\end{tabular} & 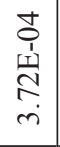 & $\begin{array}{l}n \\
o \\
1 \\
\omega \\
m \\
\sigma\end{array}$ & $\begin{array}{l}n \\
o \\
1 \\
\\
\sigma \\
\dot{r}\end{array}$ & 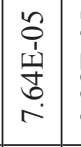 & $\begin{array}{l}n \\
0 \\
1 \\
1 \\
0 \\
\\
\end{array}$ & $\begin{array}{c}n \\
o \\
1 \\
\infty \\
\infty \\
\vec{a} \\
\end{array}$ & 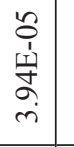 & 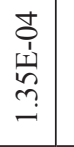 & 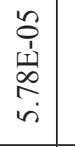 & 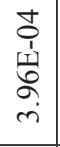 & 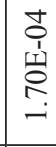 \\
\hline 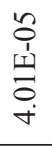 & $\begin{array}{c}n \\
o \\
1 \\
\stackrel{1}{n} \\
\stackrel{i}{i}\end{array}$ & 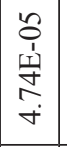 & $\begin{array}{c}n \\
0 \\
1 \\
1 \\
\\
n \\
i \\
\end{array}$ & 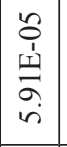 & 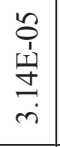 & \begin{tabular}{|c|c|} 
\\
0 \\
1 \\
to \\
0 \\
$\dot{1}$ \\
\end{tabular} & 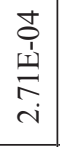 & \begin{tabular}{l}
$n$ \\
$o$ \\
1 \\
\cline { 1 - 1 } \\
$i$ \\
$n$
\end{tabular} & $\begin{array}{l}n \\
o \\
1 \\
\dot{1} \\
\infty \\
i \\
i\end{array}$ & 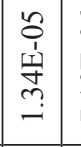 & 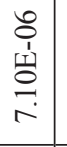 & $\begin{array}{c}n \\
o \\
1 \\
m \\
m \\
\\
\end{array}$ & $\begin{array}{l}0 \\
0 \\
1 \\
t \\
0 \\
0 \\
- \\
-\end{array}$ & 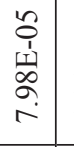 & $\begin{array}{l}\stackrel{n}{o} \\
+ \\
\stackrel{+}{+} \\
\stackrel{+}{+} \\
\dot{+}\end{array}$ & 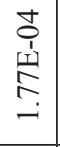 & 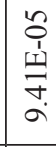 \\
\hline $\begin{array}{l}\underset{\infty}{\infty} \\
\stackrel{+}{+} \\
\stackrel{+}{+} \\
\stackrel{+}{*}\end{array}$ & 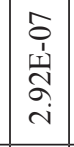 & 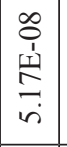 & \begin{tabular}{|c|} 
\\
0 \\
$i$ \\
1 \\
$⿱ 亠 䒑$ \\
$\dot{c}$ \\
\end{tabular} & \begin{tabular}{|c|}
0 \\
0 \\
0 \\
1 \\
1 \\
$y$ \\
$b$ \\
\\
\end{tabular} & $\begin{array}{c}\hat{1} \\
\text { 1 } \\
\text { 山े } \\
\stackrel{m}{+} \\
\dot{+}\end{array}$ & 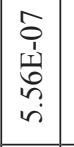 & 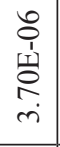 & 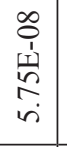 & \begin{tabular}{c}
$\hat{1}$ \\
$\dot{1}$ \\
\multicolumn{1}{|c}{} \\
$\infty$ \\
$\dot{r}$
\end{tabular} & \begin{tabular}{|l|}
$\infty$ \\
0 \\
0 \\
1 \\
1 \\
0 \\
+ \\
$\stackrel{-}{+}$ \\
\end{tabular} & 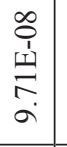 & 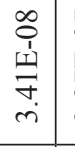 & 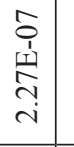 & $\begin{array}{l}\infty \\
0 \\
1 \\
1 \\
2 \\
\stackrel{1}{2} \\
\infty\end{array}$ & 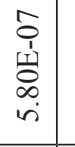 & 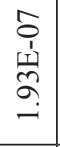 & 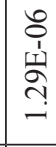 \\
\hline 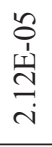 & 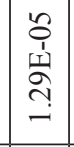 & 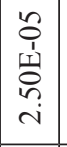 & 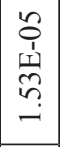 & 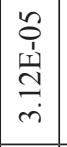 & $\begin{array}{l}n \\
o \\
1 \\
1 \\
\vdots \\
\vdots \\
- \\
-\end{array}$ & 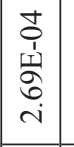 & 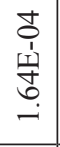 & $\begin{array}{c}2 \\
o \\
1 \\
1 \\
\stackrel{1}{0} \\
\end{array}$ & 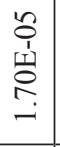 & 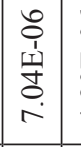 & 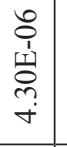 & $\begin{array}{c}n \\
o \\
1 \\
1 \\
\vdots \\
\vdots \\
- \\
-\end{array}$ & $\begin{array}{l}n \\
0 \\
1 \\
\pm \\
0 \\
0 \\
-\end{array}$ & 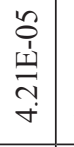 & 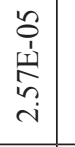 & $\begin{array}{l}n \\
o \\
1 \\
y \\
m \\
m \\
a\end{array}$ & $\begin{array}{l}2 \\
0 \\
1 \\
\text { 11 } \\
\text { in } \\
\text { in }\end{array}$ \\
\hline 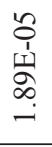 & $\begin{array}{c}\stackrel{0}{0} \\
\stackrel{1}{1} \\
= \\
= \\
\infty \\
\infty\end{array}$ & 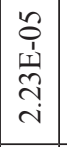 & $\begin{array}{c}0 \\
0 \\
1 \\
1 \\
0 \\
0 \\
2 \\
\sigma\end{array}$ & 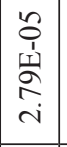 & 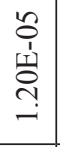 & 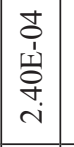 & 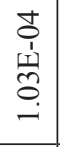 & $\begin{array}{l}n \\
o \\
1 \\
1 \\
\stackrel{1}{a} \\
i \\
i\end{array}$ & 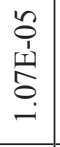 & 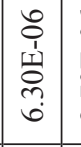 & $\begin{array}{l}\stackrel{8}{0} \\
\text { 1े } \\
\stackrel{1}{2} \\
\text { i }\end{array}$ & $\begin{array}{c}n \\
o \\
1 \\
1 \\
\infty \\
\stackrel{1}{0} \\
- \\
-\end{array}$ & 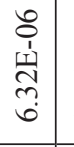 & 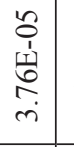 & $\begin{array}{l}n \\
0 \\
1 \\
\omega \\
0 \\
- \\
-\end{array}$ & $\begin{array}{l}n \\
0 \\
1 \\
0 \\
0 \\
\infty \\
\infty\end{array}$ & $\begin{array}{l}n \\
0 \\
1 \\
1 \\
\infty \\
n \\
n \\
n\end{array}$ \\
\hline 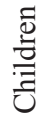 & $\frac{\vec{z}}{\frac{3}{2}}$ & 离 & $\frac{\vec{Z}}{\frac{7}{4}}$ & \begin{tabular}{|l|}
$\overline{0}$ \\
$\frac{\tilde{g}}{\bar{z}}$ \\
$\bar{z}$ \\
\end{tabular} & $\begin{array}{l}\overrightarrow{\vec{z}} \\
\frac{\vec{z}}{4}\end{array}$ & 离 & $\begin{array}{l}\vec{z} \\
\frac{\vec{z}}{2}\end{array}$ & 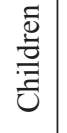 & $\begin{array}{l}\frac{\vec{Z}}{\bar{z}} \\
\frac{\theta}{4}\end{array}$ & 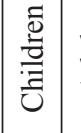 & $\frac{\vec{E}}{\vec{z}}$ & 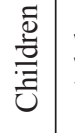 & $\frac{\vec{t}}{\frac{\pi}{4}}$ & 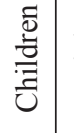 & $\frac{\vec{Z}}{\frac{Z}{2}}$ & 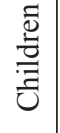 & $\frac{\vec{J}}{\vec{z}}$ \\
\hline & & \multicolumn{2}{|c|}{$\vec{q}$} & \multicolumn{2}{|c|}{3} & \multicolumn{2}{|c|}{$\hat{\theta}$} & \multicolumn{2}{|c|}{ ن્ટિ } & \multicolumn{2}{|l|}{$\exists$} & \multicolumn{2}{|c|}{$\widehat{\hat{e}}$} & \multicolumn{2}{|l|}{$\widehat{\varrho}$} & \multicolumn{2}{|c|}{ 嵒 } \\
\hline & \multicolumn{10}{|c|}{$\begin{array}{l}m \\
\stackrel{0}{n}\end{array}$} \\
\hline
\end{tabular}



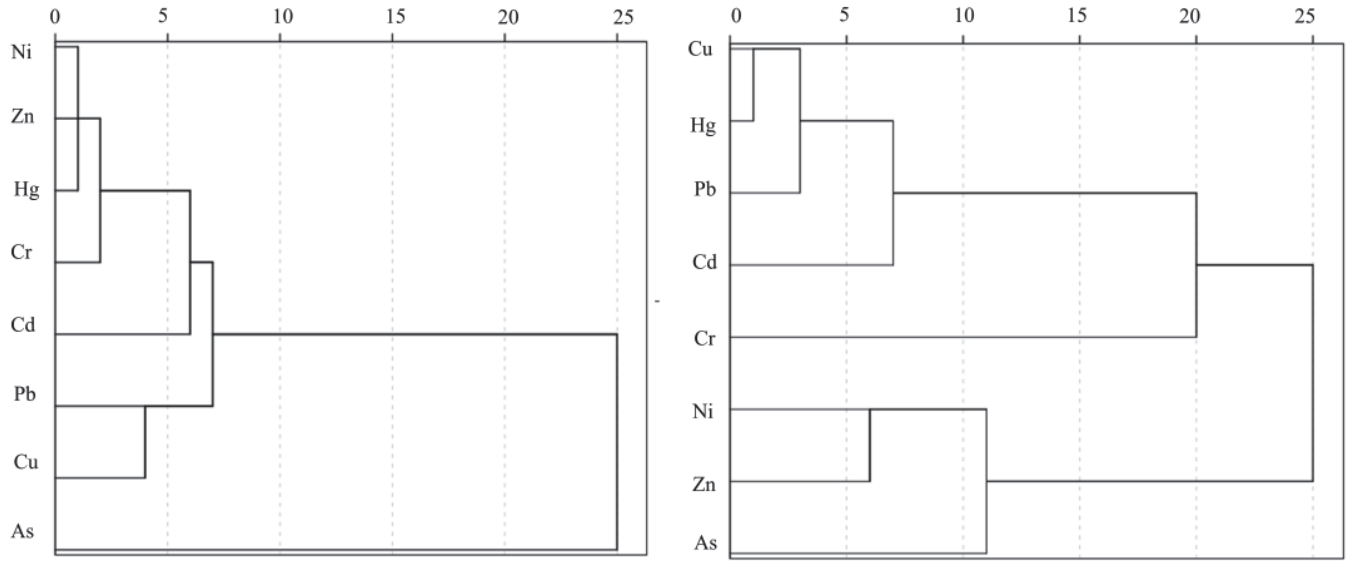

Fig. S1. Tree diagram of HCA between $\mathrm{Cd}, \mathrm{Pb}, \mathrm{Cr}, \mathrm{Cu}, \mathrm{Ni}, \mathrm{Zn}, \mathrm{As}$ and $\mathrm{Hg}$ in Site A and Site B (Site A is left, Site B is right).
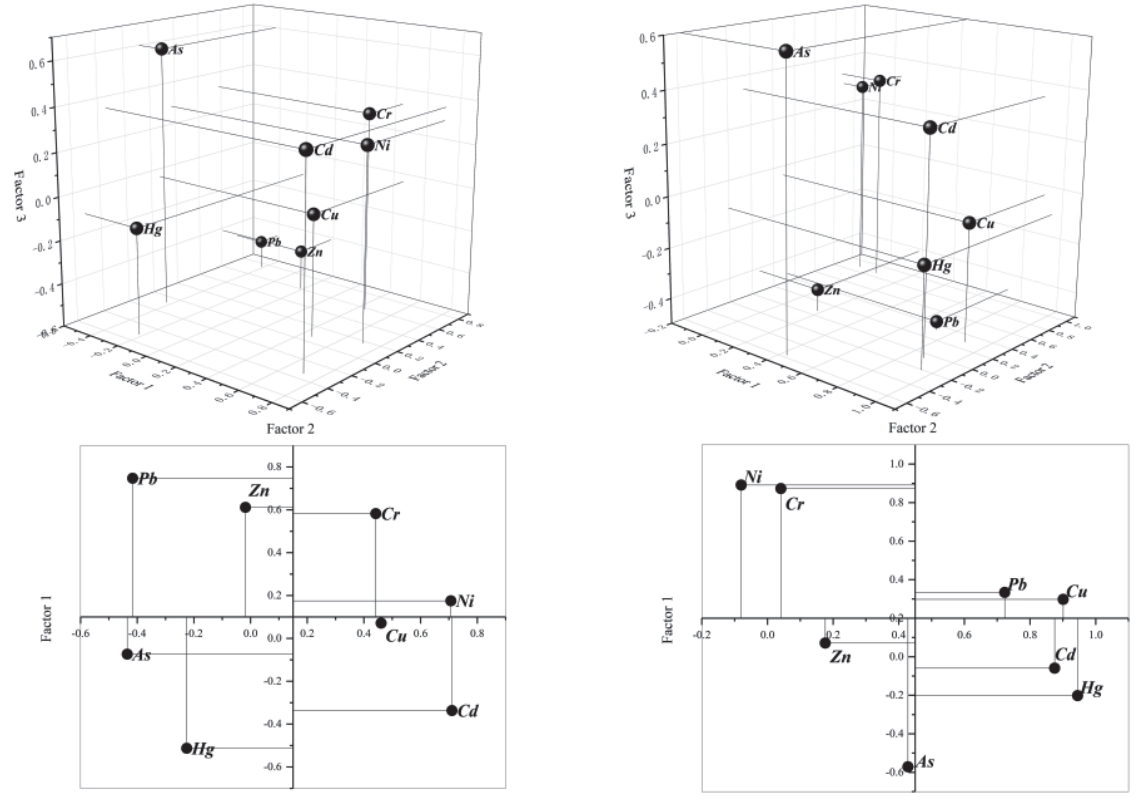

Fig. S2. Analysis results of PCA for Cd, Pb, Cr, Cu, Ni, Zn, As, $\mathrm{Hg}$ in Site A and Site B (Above is the result of three principal components, below is the result of two principal components, Site A is left, Site B is right).

\section{References}

1. TANG J.X., HE M.M., LUO Q., MUHAMMAD A., JIAO F. Heavy Metals in Agricultural Soils from a Typical Mining City in China: Spatial Distribution, Source Apportionment, and Health Risk Assessment. Polish. Journal of Environmental Studies 29, 1379, 2019.

2. US EPA. Exposure Analysis and Risk Characterization Group, Moya, J. Exposure Factors Handbook, National Center for Environmental Assessment, Washington DC, 2002.

3. LI H.M., QIAN X., HU W., WANG Y.L., GAO H.L. Chemical speciation and human health risk of trace metals in urban street dusts from a metropolitan city, Nanjing, SE China. Science of the Total Environment 456-457, 212, 2013.

4. MA W.C., TAI L.Y., QIAO Z. Contamination source apportionment and health risk assessment of heavy metals in soil around municipal solid waste incinerator: a case study in North China. Science of the Total Environment 631-632, 348, 2018.

5. SHARAREH D., FARID M., BEHNAM K., BEVERLEY A.H. Health risk implications of potentially toxic metals in street dust and surface soil of Tehran, Iran. Ecotoxicology and Environmental Safety 136, 92, 2017. 